\title{
TRPM7, Magnesium, and Signaling
}

\section{Zhi-Guo Zou®, Francisco J. Rios, Augusto C. Montezano and Rhian M. Touyz *}

Institute of Cardiovascular and Medical Sciences, BHF Glasgow Cardiovascular Centre, University of Glasgow, Glasgow G12 8TA, UK; z.zou.1@research.gla.ac.uk (Z.-G.Z.); francisco.rios@glasgow.ac.uk (F.J.R.); augusto.montezano@glasgow.ac.uk (A.C.M.)

* Correspondence: Rhian.Touyz@glasgow.ac.uk; Tel.: +44-(0)141-330-7775 (ext. 7774); Fax: +44-(0)141-330-3360

Received: 18 March 2019; Accepted: 12 April 2019; Published: 16 April 2019

Abstract: The transient receptor potential melastatin-subfamily member 7 (TRPM7) is a ubiquitously expressed chanzyme that possesses an ion channel permeable to the divalent cations $\mathrm{Mg}^{2+}, \mathrm{Ca}^{2+}$, and $\mathrm{Zn}^{2+}$, and an $\alpha$-kinase that phosphorylates downstream substrates. TRPM7 and its homologue TRPM6 have been implicated in a variety of cellular functions and is critically associated with intracellular signaling, including receptor tyrosine kinase (RTK)-mediated pathways. Emerging evidence indicates that growth factors, such as EGF and VEGF, signal through their RTKs, which regulate activity of TRPM6 and TRPM7. TRPM6 is primarily an epithelial-associated channel, while TRPM7 is more ubiquitous. In this review we focus on TRPM7 and its association with growth factors, RTKs, and downstream kinase signaling. We also highlight how interplay between TRPM7, $\mathrm{Mg}^{2+}$ and signaling kinases influences cell function in physiological and pathological conditions, such as cancer and preeclampsia.

Keywords: TRPM7; magnesium transporters; receptor tyrosine kinases; VEGFR; EGFR

\section{Introduction}

The transient receptor potential melastatin 7 (TRPM7) and its close homologue TRPM6 share the unique feature of a cation channel fused to a C-terminal $\alpha$-kinase domain [1-3]. TRPM6 and TRPM7 are present in a tetrameric form and each subunit comprises six transmembrane segments (S1-6), and a channel pore permeable to $\mathrm{Mg}^{2+}, \mathrm{Ca}^{2+}$, and $\mathrm{Zn}^{2+}$, located between segments 5 and 6 (Figure 1) [4,5]. TRPM7 is ubiquitously expressed, whereas TRPM6 is mostly expressed in cells from kidneys and intestines. In spite of their similarities, they are not compensated by each other, indicating that they are not redundant. TRPM7 was initially proposed to regulate, and itself to be regulated by, intracellular $\mathrm{Mg}^{2+}$ levels, with Mg-ATP below $1 \mathrm{mM}$ strongly activating the channel [6]. The importance of TRPM7 in cellular $\mathrm{Mg}^{2+}$ homeostasis has been investigated in several cell types, including leukocytes, platelets, vascular smooth muscle cells (VSMCs), cardiomyocytes, cardiac fibroblasts, osteoblasts, and tumor cells, in both physiological and pathological conditions [6-13]. Experiments using TRPM7 overexpressing cells demonstrated important mechanisms underlying the role of TRPM7 in $\mathrm{Mg}^{2+}$ homeostasis, and this was confirmed in the recently described crystal structure of mouse TRPM7, where partially hydrated $\mathrm{Mg}^{2+}$ ions occupy the center of the conduction pore [3]. However, the importance of TRPM7 in $\mathrm{Mg}^{2+}$ homeostasis has also been questioned by some studies, since the deletion of TRPM7 in T cells did not affect acute uptake or the maintenance of total cellular $\mathrm{Mg}^{2+}$ [14]. However, this may relate to the cell type studied, because $\mathrm{Mg}^{2+}$ is typically regulated by MagT1 in immune cells. 


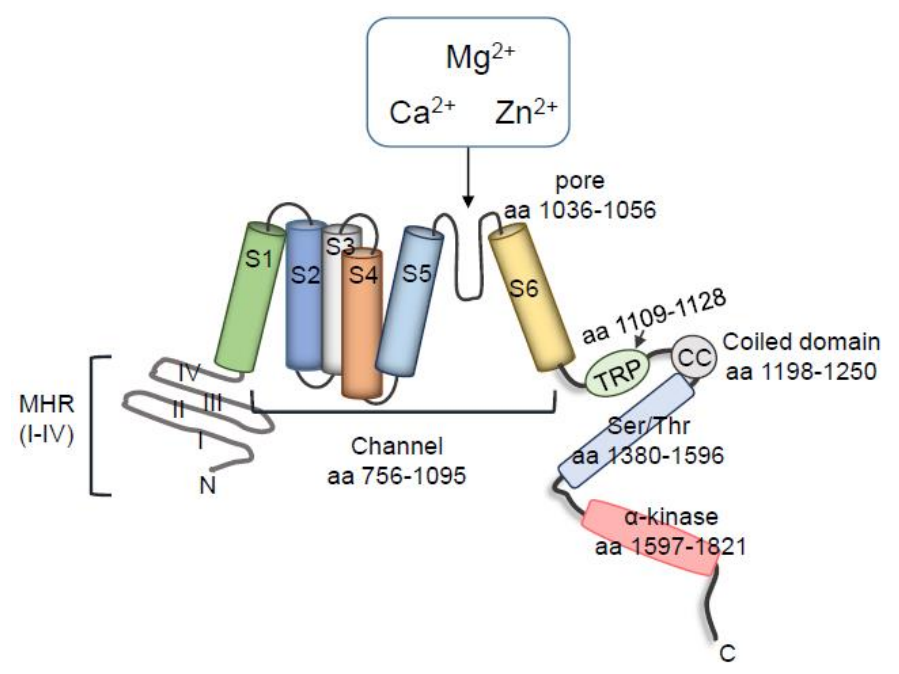

Figure 1. Schematic structure of the TRPM7 channel and kinase. The general structure of the TRPM7 has four Melastatin Homologous Regions (MHR) in the N-terminal domain, and six transmembrane segments (aa 756-1095). The pore (aa 1039-1056) is located between the S5 and S6. The C terminal domain contains the transient receptor potential (TRP) region (aa 1109-1128), common to TRP family members, followed by the coiled coil (CC) domain connecting loop (aa 1198-1250); Serine- and threonine-rich domains (aa 1380-1596), and the $\alpha$-kinase domain (aa 1597-1821).

TRPM6 and TRPM7 have been linked to many signaling pathways. Emerging evidence indicates an important role for these systems in growth factor signaling through receptor tyrosine kinases (RTK). The C-terminal $\alpha$-kinase domain induces phosphorylation of many downstream targets involved in RTK signaling including annexin A1, calpain II, myosin II, PLC $\gamma 2$, Src, and SMAD2 [15], and regulates epigenetic modifications [16]. TRPM7 kinase domain may also influence TRPM7 channel function, although the exact mechanisms remain unclear [17-19].

In addition to controlling $\mathrm{Mg}^{2+}$ transport across cell membranes, TRPM7, together with other $\mathrm{Ca}^{2+}$ channels, regulates $\mathrm{Ca}^{2+}$ influx in many cell types $[20,21]$. In angiotensin II (Ang II)-stimulated cardiac fibroblasts, TRPM7 is functionally active and controls both $\mathrm{Mg}^{2+}$ and $\mathrm{Ca}^{2+}$ influx [9]. In neuroblastoma cells, bradykinin-induced activation of TRPM7 mediates $\mathrm{Ca}^{2+}$ influx in a kinase-independent manner [22] and $\mathrm{Ca}^{2+}$ entry in macrophages triggered by lipopolysaccharide (LPS) is controlled by TRPM7, as observed in a cell-specific deletion model using a Cre/Lox system [23]. The kinase domain of TRPM7 also plays an important role in $\mathrm{Ca}^{2+}$ homeostasis by modulating store-operated calcium channels (SOCE) [24,25].

TRPM7 is also permeable to $\mathrm{Zn}^{2+}$ and may be an important regulator of cellular $\mathrm{Zn}^{2+}$ dynamics. This was originally identified in mouse cortical neurons, where activation of TRPM7 channels increased intracellular $\mathrm{Zn}^{2+}$, and TRPM7 knockdown using a short hairpin RNA reduced TRPM7-like current and intracellular $\mathrm{Zn}^{2+}$ concentration [26]. Additionally, a recent study showed that TRPM7 is an intracellular $\mathrm{Zn}^{2+}$ storage vesicle, which sequesters $\mathrm{Zn}^{2+}$ during cytosolic overload, and releases $\mathrm{Zn}^{2+}$ under oxidizing conditions [27]. Interestingly, other channels from the TRPM family are also permeable to $\mathrm{Zn}^{2+}$, such as TRPM2, TRPM3, and TRPM5 [28-30].

Receptor tyrosine kinases (RTKs), through which growth factors signal, are membrane-associated receptors [31]. Upon growth factor binding, autophosphorylation of RTKs induces phosphorylation and activation of intracellular non-receptor tyrosine kinases that influence phosphorylation of downstream target proteins. The activation of RTKs is involved in critical signaling pathways and cell functions, including proliferation, differentiation, migration and contraction, processes also dependent on $\mathrm{Mg}^{2+}$ and $\mathrm{Ca}^{2+}$. The RTK family comprises major growth factor receptors, such as epidermal growth factor receptor (EGFR), vascular endothelial growth factor receptor (VEGFR), platelet-derived growth factor 
receptor (PDGFR), nerve growth factor receptor (NGFR), fibroblast growth factor receptor (FGFR), and insulin-like growth factor receptor (IGFR) [32].

In 2009, Bindels and colleagues demonstrated that EGF activates EGFR signaling and promotes TRPM6 translocation from the cytosol to the membrane in kidney cells, through Src family tyrosine kinases [33]. These effects were abolished by the monoclonal antibody specific to EGFR (cetuximab) [33,34]. Similar effects were observed in mice treated with erlotinib [35] and in mammary epithelial cells treated with tyrphostin AG1478, inhibitors of EGFR tyrosine kinase [36]. These studies were amongst the first to show a relationship between TRPM6, $\mathrm{Mg}^{2+}$ and growth factors and might explain the severe hypomagnesemia observed as a side effect in cancer patients treated with EGFR inhibitors [37]. Most clinical trials reported electrolyte disorders, particularly hypomagnesemia and hypocalcemia, in cancer patients treated with EGFR inhibitors [34]. Whether EGFR inhibitors also influence TRPM7 in cancer patients is unclear.

\section{Transient Receptor Potential Melastatin 7 Cation Channel (TRPM7)}

\subsection{Characteristics and Regulation of TRPM7}

Among the more than 300 mammalian ion channels, only TRPM7 and TRPM6 have a C-terminal kinase, which belongs to a specific subfamily of atypical protein kinases (APKs), known as $\alpha$-kinases, displaying little amino acid sequence similarity to conventional protein kinases [3,38,39]. To date very few $\alpha$-kinases have been identified. Those that have been described include eukaryotic Elongation Factor 2 Kinase (eEF2K), alpha-kinase 1 (lymphocyte alpha-kinase, LAK or ALPK1), alpha-kinase 2 (heart alpha-kinase, HAK or ALPK2) and alpha-kinase 3 (muscle alpha-kinase, MAK or ALPK3), TRPM6 and TRPM7 [38]. The crystal structure of TRPM7 shows that the N-terminal central catalytic core is structurally similar to the classical protein kinase, whereas the structure of the C-terminal lobe resembles metabolic enzymes with ATP-grasp folds [3,39]. The TRPM7 $\alpha$-kinase predominantly phosphorylates serine/threonine residues on $\alpha$-helices. Since the cytoplasmic domain is rich in serine/threonine residues, activation of TRPM7 can induce autophosphorylation as well as phosphorylation of downstream targets (Figure 1) [40,41]. TRPM7-kinase phosphorylates annexin-A1 (Ser5) [42]; myosin IIA (Thr1800, Ser1803 and Ser1808) [43]; eukaryotic elongation factor 2 cognate kinase (eEF2-K) (Ser77) under low $\mathrm{Mg}^{2+}$ concentrations [44]; SMAD2 (Ser465/467) [15]; and phospholipase C $\gamma 2$ (PLC $\gamma 2$ ) (Ser1164) [45]. TRPM7 is cleaved by caspases at Asp1510, dissociating the kinase from the conducting pore, with the cleaved channel exhibiting enhanced activity, and the kinase domain retaining phosphotransferase activity [46]. TRPM7 cleaved fragments translocate and accumulate in the nucleus, where they phosphorylate specific serines and threonines on histones, affecting gene expression. It seems that different cleaved fragments are expressed in different tissues, implying a distinct role for TRPM7 cleaved fragments in a tissue-specific manner [16]. A similar phenomenon has been described for TRPM6 kinase [47].

\subsection{Interactions between TRPM7 Kinase and TRPM7 Channel Domains}

Despite intense investigations, there are still controversies regarding the functional significance of the coupling between the $\alpha$-kinase and the channel domain of TRPM7. Mutations at specific sites that disrupt kinase activity do not affect TRPM7 channel activity and sensitivity to inhibition by divalent cations (Figure 2). In addition, there were no significant differences in channel activity and $\mathrm{Ca}^{2+}$ influx between wild type and TRPM7 kinase mutant cells [48]. These data were confirmed in in vivo experiments, where TRPM7 kinase-dead mutant mice have normal serum $\mathrm{Mg}^{2+}$ levels and normal development $[15,19,48]$. However, many studies support a link between TRPM7 channel and its C-terminal kinase. In HEK293 cells overexpressing mutant human TRPM7 K1648R and G1799D, activity of the kinase domain and function of the channel domain are altered by changes in sensitivity to intracellular $\mathrm{Mg}^{2+}$ [49]. Interplay between the kinase and channel is supported by studies showing that: (i) cleavage of TRPM7 kinase is associated with increased cation channel activity [46], (ii) $\mathrm{Mg}^{2+}$ nucleotide modulation of TRPM7 channel through the kinase domain [50,51], and (iii) regulation of 
TRPM7 by cAMP/PKA, which requires a functional kinase domain [52]. Additionally, an in vivo model carrying a truncated kinase domain showed reduced intracellular $\mathrm{Mg}^{2+}$, hypomagnesemia [17] and increased sensitivity to $\mathrm{Ca}^{2+}$ in mast cells [53]. Therefore, it seems that the catalytic activity of the kinase is not essential for channel gating, but somehow it modulates and "fine tunes" channel activity and sensitivity to $\mathrm{Mg}^{2+}$ nucleotides.

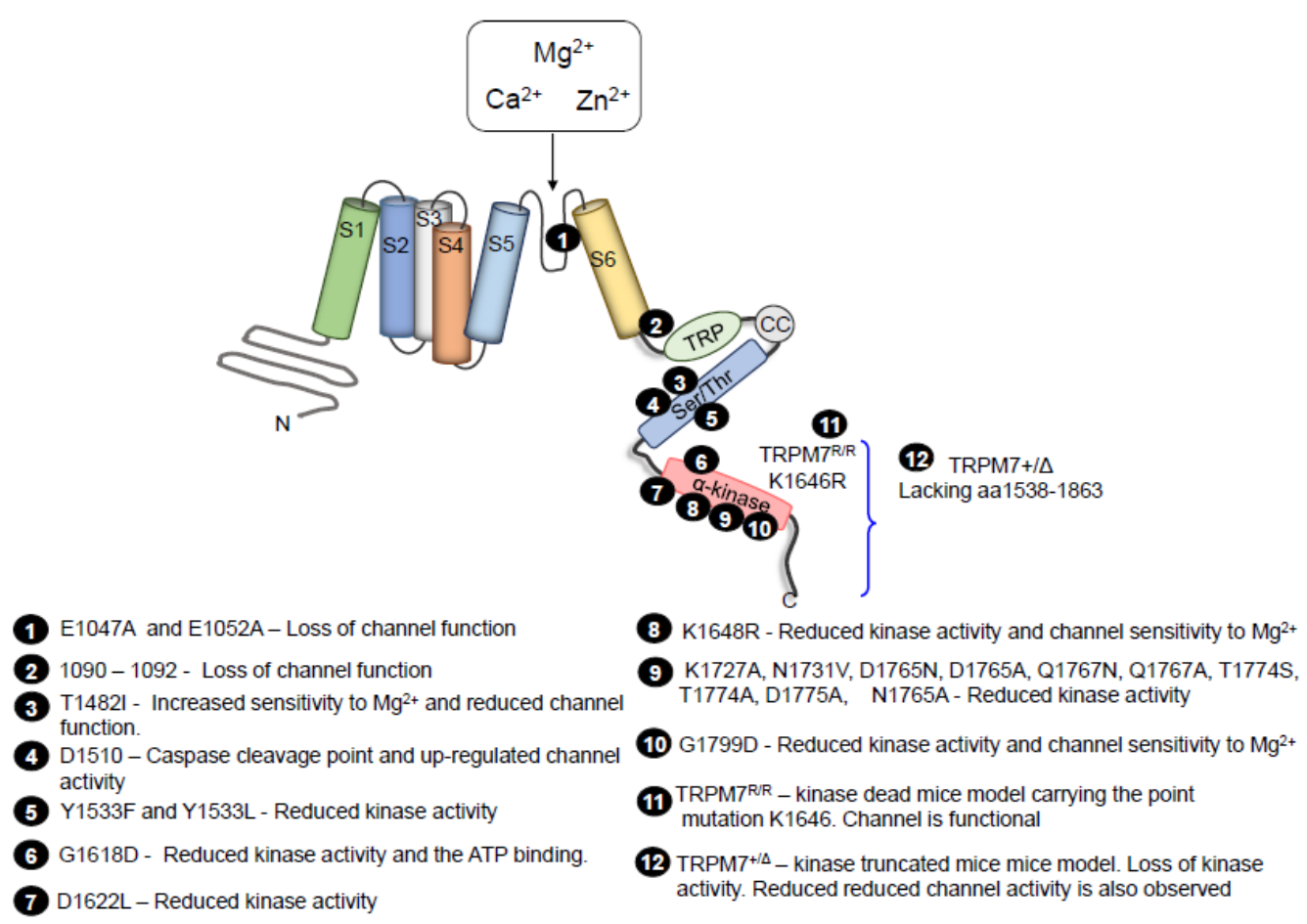

Figure 2. Schematic overview of TRPM7 mutations. Mutations that have been identified are highlighted. Numbers indicate the single amino acids or regions that affect TRPM7 channel or kinase activity $[17,19$, $46,48,49,54-59]$.

\subsection{Relationship between TRPM6 and TRPM7}

In the plasma membrane, TRPM7 functions as a homodimer, but in some conditions it also heterodimerizes with TRPM6. In some cell-based systems, TRPM6 seems to require TRPM7 for full activation and in the complexed state has been termed TRPM6/TRPM7 [60]. The crucial role of TRPM7 in the complex formation was demonstrated in molecular studies, where TRPM6 deficiency in trophoblast stem cells results in a reduction in TRPM6/7 currents, while deficiency in TRPM7 completely abolished the TRPM6/7 currents [53]. TRPM6 and TRPM7 possess several phosphorylation sites and can be phosphorylated independently of autophosphorylation, TRPM7 can also be transphosphorylated by TRPM6 (Figure 3) [61]. This cross activation was demonstrated in co-transfection experiments, which showed that TRPM6 expression was able to transphosphorylate serine and threonine motifs in TRPM7-K1646R kinase dead mutant. Transphosphorylation of TRPM6 by TRPM7 is very weak. These phosphorylated residues are present in the $\mathrm{N}$-terminal, channel, and $\mathrm{C}$ terminus, including the kinase domain of the TRPM7-K1646R [61]. These phenomena have been demonstrated in cell models but the (patho) physiological significance in vivo remains to be determined. TRPM7 seems to interact with other $\mathrm{Mg}^{2+}$ channels. In DT40 B cells and colon carcinoma cells, TRPM7 deficiency was associated with increased expression of MagT1 [62-64]. 


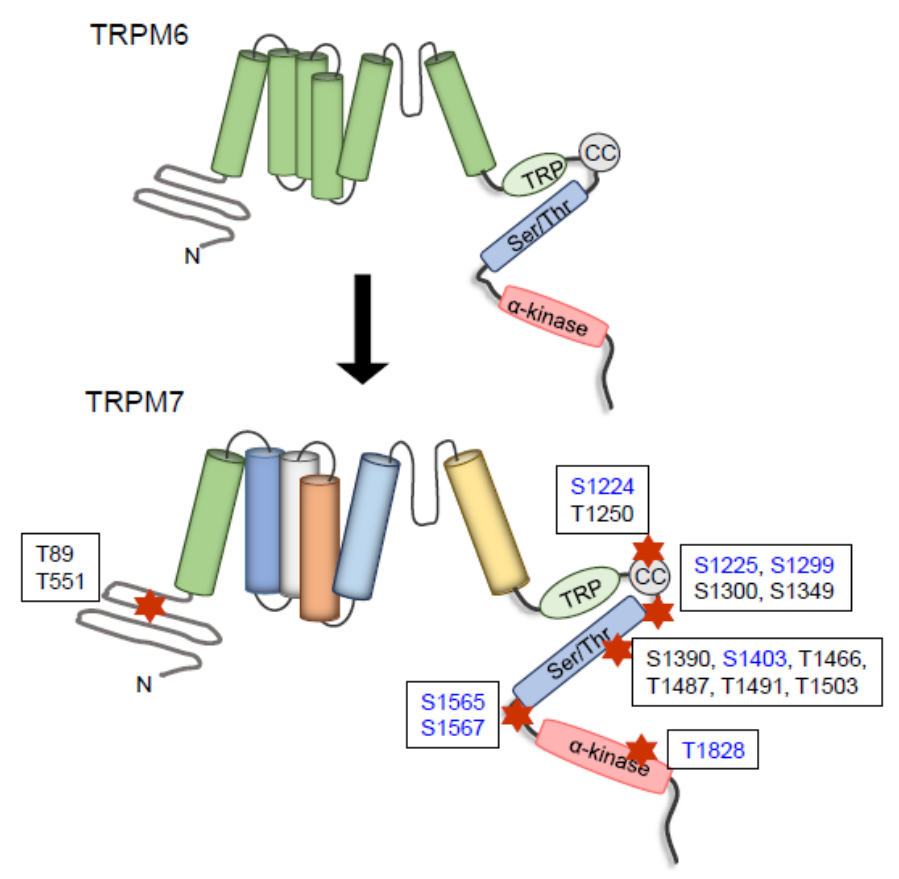

Figure 3. Transphosphorylation of TRPM7 by TRPM6. TRPM6 is able to induce phosphorylation of TRPM7 in the indicated residues. Red stars indicate the location of the residues. Residues in blue are also residues of autophosphorylation.

\subsection{TRPM7 and Cell Function}

The indispensable role of TRPM7 in cellular biology is likely linked to its important role in the regulation of homeostasis of divalent cations $\mathrm{Mg}^{2+}, \mathrm{Zn}^{2+}$, and $\mathrm{Ca}^{2+} \cdot \mathrm{Mg}^{2+}$ and $\mathrm{Zn}^{2+}$ are catalytic and structural cofactors of numerous enzymes and are major regulators of signaling molecules, DNA stability, cell cycle and transcription factors $[65,66]$. Deficiency of $\mathrm{Mg}^{2+}$ and $\mathrm{Zn}^{2+}$ suppress cell cycle progression leading to growth failure $[67,68] . \mathrm{Mg}^{2+}$ supplementation and overexpression of $\mathrm{Mg}^{2+}$ transporters rescued growth impairment caused by TRPM7 deficiency $[17,62] . \mathrm{Ca}^{2+}$, which is also influenced by TRPM7, is critically involved in controlling cell function including cell proliferation, contraction, secretion, migration and differentiation [69-71]. Associated with many of the $\mathrm{Ca}^{2+}$ - and $\mathrm{Mg}^{2+}$ - regulated signaling pathways is the activation of tyrosine kinases [35,72-75]. In vascular cells, TRPM7 appears to be the most important cation channel involved in controlling $\left[\mathrm{Mg}^{2+}\right]_{\mathrm{i}}$. TRPM7 is regulated by vasoactive factors, such as AngII, aldosterone, endothelin-1 and bradykinin [76-80]. Ang II regulates vascular TRPM7 acutely by inducing phosphorylation and chronically by increasing expression at the mRNA and protein levels [76,79]. Also, siRNA downregulation of vascular TRPM7 caused a reduction in $\left[\mathrm{Mg}^{2+}\right]_{i}$ and attenuated Ang II-mediated VSMC growth [7]. VSMCs from hypertensive rats exhibit reduced TRPM7 expression and decreased TRPM7 activation, as assessed by translocation of annexin-1 (TRPM7 kinase target) to the membrane [79]. Findings from cell-based studies and animal models indicate that TRPM7 activation and increased $\mathrm{Mg}^{2+}$ influx are vasoprotective as they protect against vascular calcification, oxidative stress and fibrosis [81].

\section{Receptor Tyrosine Kinase Signaling and $\mathrm{Mg}^{2+}$}

\subsection{Characteristics and Regulation of Receptor Tyrosine Kinases}

Protein kinases induce phosphorylation by catalyzing the transfer of phosphate from adenosine triphosphate (ATP) to serine, threonine and tyrosine residues on protein substrates and are key enzymes in the regulation of intracellular signaling pathways $[82,83]$. These ATP- and phosphate-dependent processes have an obligatory requirement for $\mathrm{Mg}^{2+}$. Data from the human genome revealed that of the proteins phosphorylated on tyrosine residues, $\approx 58$ are receptor tyrosine kinases and $\approx 32$ are 
non-receptor tyrosine kinases [32,84]. All RTKs have a similar molecular architecture, comprising three major domains, including an extracellular ligand-binding domain, an intracellular tyrosine kinase domain and a transmembrane domain [31]. RTKs are typically activated by growth factors [85-88].

Magnesium is a crucial divalent cation required for the activity of protein kinases, including RTKs (VEGFR, EGFR, FGFR, PDGFR) and non-receptor tyrosine kinases (Src, Abl, Jak, FAK, SOCS) [89]. In cell-based studies, high $\mathrm{Mg}^{2+}$ concentration causes increased tyrosine kinase activity. Data obtained with crystallography experiments revealed that two $\mathrm{Mg}^{2+}$ molecules are required for enzyme activity and phosphoryl transfer: one bound to ATP (Mg-ATP) situated between the small and large lobes of the kinase domain, bound to $\beta$ and $\gamma$-phosphates and to the aspartate of the DFG (Asp-Phe-Gly), which are the first residues to be activated in protein kinases; and in high $\left[\mathrm{Mg}^{2+}\right]_{\mathrm{i}}$ conditions, another $\mathrm{Mg}^{2+}$ binds to $\alpha$ and $\gamma$-phosphates and to the asparagine amide nitrogen within the catalytic loop [90]. The importance of $\mathrm{Mg}^{2+}$ in the regulation of kinase activity occurs in four steps: (i) Mg-ATP binds to the enzyme; (ii) the kinase binds to the protein substrate and catalyzes the transfer of the phosphoryl group; (iii) phosphorylated protein and $\mathrm{Mg}^{2+}$ are released; and (iv) $\mathrm{Mg}^{2+}$-ADP is released and the catalytic cycle is completed [91] (Figure 4).

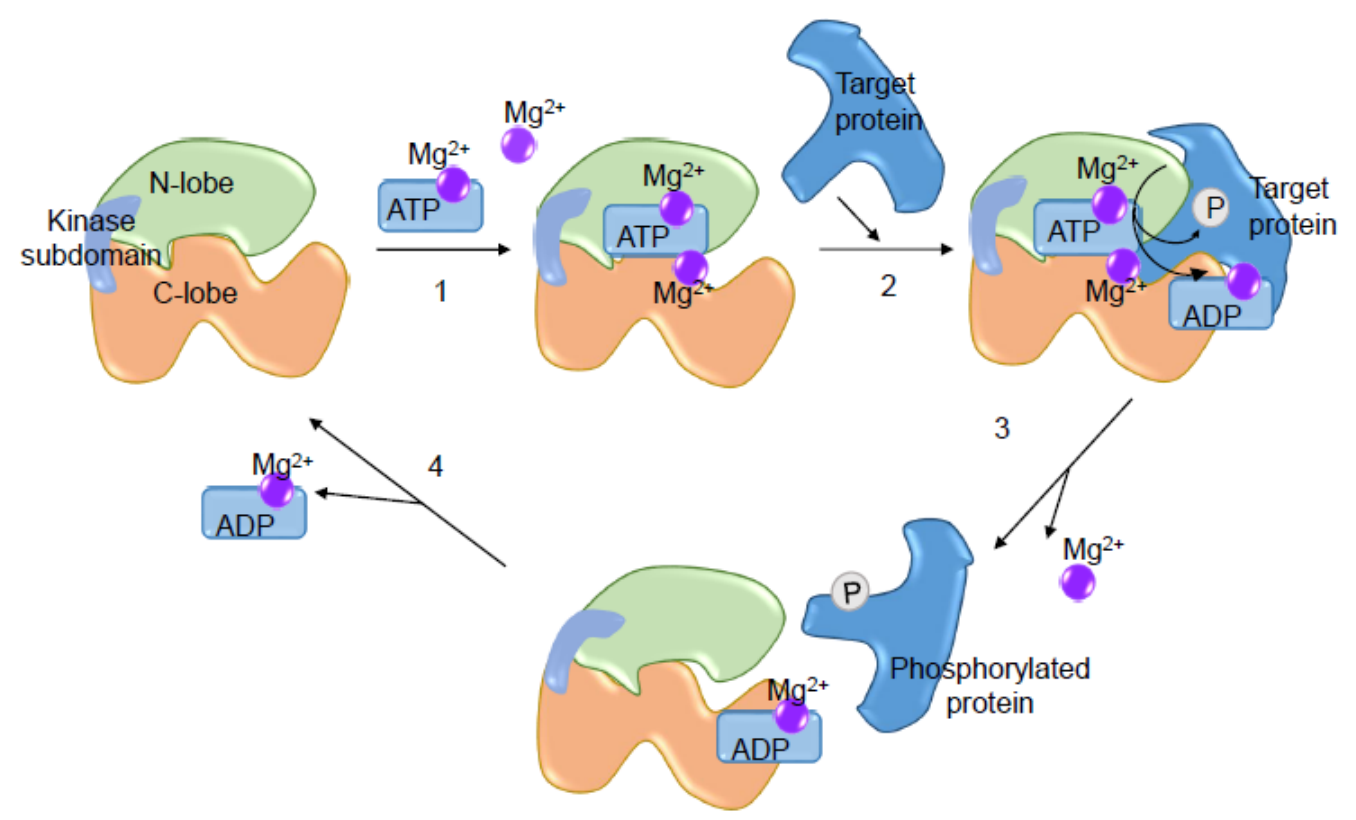

Figure 4. Importance of $\mathrm{Mg}^{2+}$ for the kinase catalytic activity. Two $\mathrm{Mg}^{2+}$ molecules are required for enzymatic activity and phosphoryl transfer: one bound to ATP (Mg-ATP) situated between the small (N-lobe) and large lobe (C-Lobe) of the kinase domain, and another $\mathrm{Mg}^{2+}$ situated in the catalytic loop. (1) Mg-ATP is the first to bind to the enzyme followed by $\mathrm{Mg}^{2+}$; (2) the kinase binds to the protein substrate and catalyzes the transfer the phosphoryl group; (3) phosphorylated protein and $\mathrm{Mg}^{2+}$ are released; and (4) Mg-ADP is released and the catalytic cycle is finalized.

\subsection{Growth Factors and Receptor Tyrosine Kinase Signaling}

Following binding of growth factors to their specific RTKs, cytoplasmic proteins containing Src homology region 2 (SH2) or phosphotyrosine-binding (PTB) domains are recruited to the cell membrane. These recruited proteins either have intrinsic enzymatic activity, such as Src and PLC $\gamma$, or serve as docking proteins that function as "assembly platforms" and recruit additional enzymes [32,75,85,92]. Activated RTKs are able to trigger a wide range of downstream signaling pathways, including RAS/RAF/MEK/MAPK, PLC $\gamma /$ PKC, PI3K/AKT/mTOR, and JAK/STAT (Figure 5) [93]. 


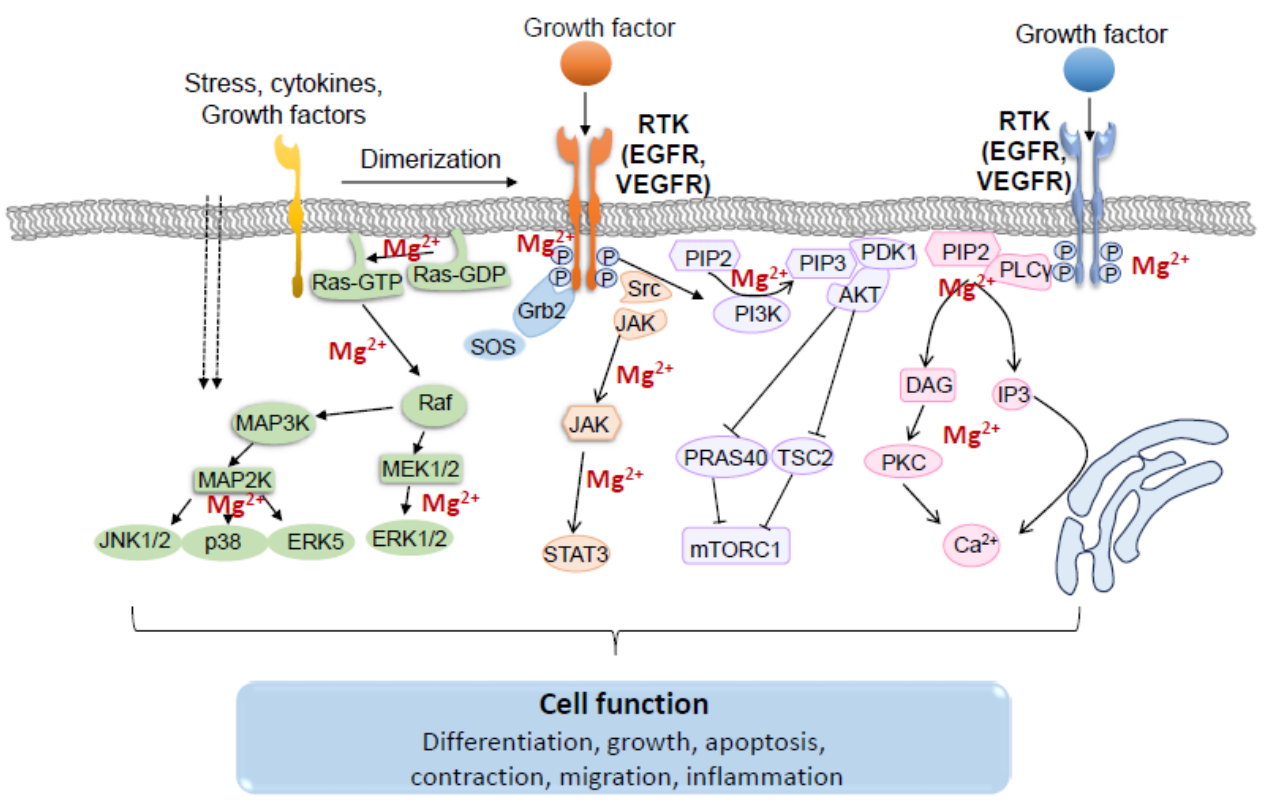

Figure 5. Schematic representation of main signaling pathways activated by growth factor signaling through receptor tyrosine kinases (RTK) and the importance of $\mathrm{Mg}^{2+}$. Ligand-induced dimerization triggers transphosphorylation of tyrosine residues located in the receptor chain, resulting in activation of RTKs. Intracellular signaling cascades activated by RTKs include the MAPK pathway, the PI3K/AKT/mTOR pathway, the JAK/STAT pathway, the PLC $\gamma /$ PKC pathway and the Src pathway. The functional response of these signals plays an essential role in the regulation of many physiological processes. Dotted arrows indicate activation through the cell membrane; Solid arrows indicate activation of target protein; $\mathrm{T}$ indicates inhibition.

Activated RTKs bind to the adaptive protein growth factor receptor-bound 2(Grb2) and recruit Son of Sevenless homolog protein (SOS), which interacts with its downstream target Ras, a small GTP binding protein, and transforms it to the active conformation by exchanging GDP for GTP [94]. Ras recruits the serine/threonine protein kinase, Raf, to the membrane, where it becomes activated by phosphorylation. Once activated, Raf, a MAP3K, phosphorylates MAP2Ks, MEK1 and MEK2, at specific serine residues, and activated MEK1/2 in turn catalyzes phosphorylation of ERK1/2 at threonine and tyrosine residues [95]. Activated ERK1/2 phosphorylates many downstream target proteins and transcription factors involved in cell function [32,96].

The phosphoinositol-3-kinase (PI3K)/Akt/mammalian target of rapamycin (mTOR) signaling pathway is also initiated by binding of growth factors to RTKs. Activated RTKs recruit the PI3K to the plasma membrane where the PI3K subunit p110 catalyzes phosphorylation of phosphatidylinositol 4,5-bisphosphate (PIP2) to phosphatidylinositol 3,4,5-triphosphate (PIP3). PIP3 then provides docking sites for signaling proteins, including AKT and 3-phosphoinositide-dependent kinase 1 (PDK1) [97,98]. Activated AKT phosphorylates many other downstream proteins, such as glycogen synthase kinase 3 (GSK3), the forkhead family of transcription factors (FOXOs) and mTOR. Multiple components of the PI3K/AKT/mTOR pathway activated by RKTs play a pivotal role in the regulation of cell growth, proliferation and differentiation [93,98-100].

Another signaling system linked to RTKs is PLC $\gamma /$ protein kinase C (PKC). Upon growth factor stimulation, the phosphorylated tyrosine residues of RTKs interact with SH2 domains of PLC $\gamma$ and lead to its activation. PLC $\gamma$ then hydrolyses PIP2 into two second messengers, inositol 1,4,5-trisphosphate (IP3) and diacylglycerol (DAG). IP3 binds to its receptor on the endoplasmic reticulum (ER) surface, whereas DAG mediates activation of PKC [101,102]. This process has a key role in regulating intracellular $\mathrm{Ca}^{2+}$ through multiple $\mathrm{Ca}^{2+}$ channels [103-105]. PLC $\gamma / \mathrm{PKC}$ is also involved in the regulation of cell proliferation, contraction and migration [106-108]. 
The Janus kinase/signal transducer and activator of transcription (JAK/STAT) and the Src family kinases (SFKs) are additional signaling pathways associated with RTK activation. Src family members, including Src, Fyn and Yes, are recruited on RTKs, such as EGFR, FGFR and IGFR, and transmit mitogenic signals to regulate DNA synthesis, cell survival, cell adhesion, motility and growth [32]. Once activated, STATs enter the nucleus and bind to specific regulatory sequences in target genes regulating transcription [109].

\section{Cross-Talk between TRPM6/7, Receptor Tyrosine Kinases and Signaling Kinases}

\subsection{Regulation of TRPM6/7 by Receptor Tyrosine Kinases}

Upon ligand binding, VEGFR and EGFR undergo receptor dimerization and tyrosine phosphorylation leading to recruitment of effector proteins and activation of downstream cascades. These processes are highly regulated and are dependent on intracellular $\mathrm{Mg}^{2+}$. Increased RTK activation and abnormal growth factor-mediated tyrosine kinase signaling is associated with uncontrolled cell proliferation in cancer [110]. Accordingly, inhibitors of VEGFR and EGFR tyrosine kinases have been used to treat several cancers. However unexpectedly these drugs have been associated with unwanted secondary effects, including hypertension, cardiovascular and renal toxicity, and electrolyte disorders [110-113].

One of the most significant electrolyte abnormalities associated with EGFR inhibitors in the treatment of cancer is renal magnesium wasting and hypomagnesemia. In extreme cases, patients need intravenous magnesium treatment and withdrawal of the EGFR inhibitor. This has major impact on the effectiveness of cancer treatment [110-114]. Molecular mechanisms underlying these side effects have been attributed to abnormal function of TRPM6, phenomena that were first described in patients carrying a mutation in the EGF gene and who have severe hypomagnesemia and cognitive disability. EGF binding to EGFR promotes TRPM6 translocation from cytosol to membrane in kidney cells [33]. This process was blocked by the EGFR monoclonal antibody, cetuximab [33,34]. Hence, EGF-EGFR signaling involves TRPM6, which promotes $\mathrm{Mg}^{2+}$ transport into cells. Inhibition of these processes with EGFR inhibitors decreases TRPM6 activity and reduces $\mathrm{Mg}^{2+}$ influx into cells, promoting $\mathrm{Mg}^{2+}$ excretion in the kidney with resultant $\mathrm{Mg}^{2+}$ wasting and hypomagnesemia.

Emerging evidence suggests that TRPM7 may also be regulated by growth factor signaling through EGFR, as well as VEGFR [115-117]. Studies in transfected chinese hamster ovary (CHO) cells showed inhibition of TRPM7 channel activity by EGF through mechanisms involving PLC $\gamma$ and PIP2 [117]. However, Gao et al. found that in pulmonary cancer cell lines, EGF, through its receptor, enhanced the cell membrane protein expression and currents of TRPM7, a process associated with cell migration [118]. The difference in models and cell lines may explain the conflicting data obtained in these two studies. In hippocampal neurons, nerve growth factor (NGF) signals through receptor tyrosine kinase TrkA, reducing the outward rectifying TRPM7-like current, effects blocked by inhibitors of TrkA and PLC [119]. TrkA activation by NGF prevented upregulation of TRPM7 expression through PI3K in hippocampal neurons subjected to ischemia-reperfusion and oxygen-glucose deprivation [120]. Moreover, PDGF stimulation was shown to increase TRPM7 expression in HSC-T6 hepatic stellate cells. The non-specific TRPM7 inhibitor 2-aminoethyl diphenyl borinate (2-APB) diminished PDGF-mediated activation of $\mathrm{p}$-AKT and p-ERK, further suggesting a regulatory role for TRPM7 upstream of AKT and ERK [121].

RTKs induce phosphorylation of downstream kinases that influence TRPM7 activity (Figure 6). However these processes seem to be related to changes in the intracellular concentration of $\mathrm{Mg}^{2+}$, because when $\left[\mathrm{Mg}^{2+}\right]_{\mathrm{i}}$ is low, PLC activation is associated with TRPM7 inhibition, whereas in normal $\left[\mathrm{Mg}^{2+}\right]_{\mathrm{i}}$ conditions, activation of PLC increases TRPM7 currents [122]. In prostate cells, TRPM7 expression was mediated by $\mathrm{Ca}^{2+}$-dependent activation of ERK, since ERK inhibition reduced TRPM7 expression [123]. Ang II, which transactivates TKRs, increased TRPM7 expression through the AT1 receptor and ERK [124]. Bradykinin, another vasoactive peptide, regulates TPRM7 and its downstream 
target annexin-1 through PLC and c-Src dependent pathways, which have an important role in VSMC $\mathrm{Mg}^{2+}$ homeostasis and cell migration and invasion [78]. The inflammatory mediator interleukin-18 (IL-18) activated TRPM7 currents and upregulated TRPM7 expression in an ERK1/2-dependent manner, processes that influence osteogenic differentiation of VSMCs [125]. In HEK293 cells, interleukin-6 (IL-6) inhibited TRPM7 currents through JAK2-STAT3 signaling and appeared to be independent of the TPRM7 $\alpha$-kinase domain. Regulation of TRPM7 by IL-6 signaling may result from JAK2-STAT3 mediated phosphorylation of TRPM7 [126].

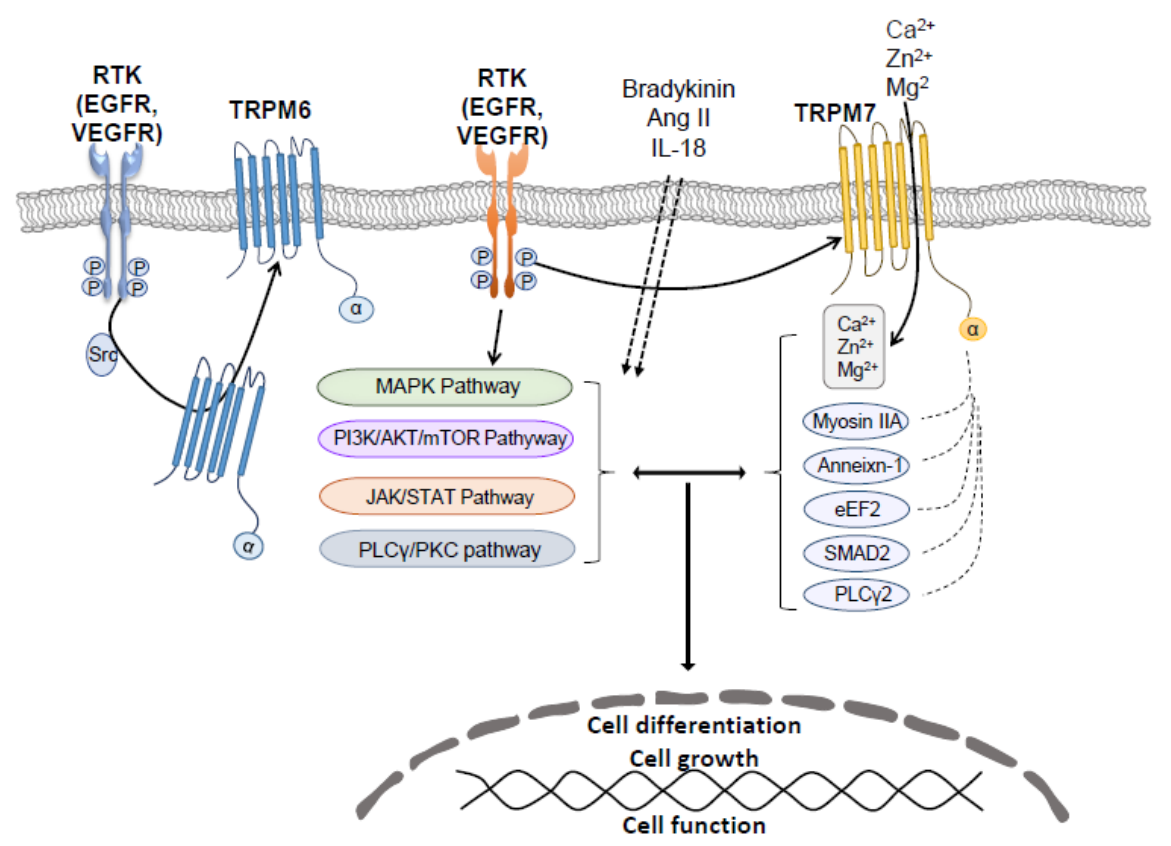

Figure 6. Cross-talk between Receptor Tyrosine Kinases (RTK) downstream signaling and TRPM7. TRPM7 has the dual properties of acting as an ion channel mainly permeable to $\mathrm{Zn}^{2+}, \mathrm{Mg}^{2+}$ and $\mathrm{Ca}^{2+}$, and as a cytoplasmic kinase, which phosphorylates annexin-1, myosin IIA heavy chain, eEF2, SMAD2, and PLC $\gamma 2$. Through either its channel or kinase, TRPM7 participates in RTK downstream signaling pathways. On the other hand, ligand induced activation of RTKs, such as EGFR, regulates the activity of TRPM7 or TRPM6. Signaling by bradykinin, Ang II, and IL-18 also influence TRPM7 activity. Dotted arrows indicate activation through the cell membrane; Solid arrows indicate activation of target protein; $\mathrm{T}$ indicate inhibition.

\subsection{Regulation of Signaling Kinases by TRPM7}

While kinases regulate TRPM7, these kinases themselves may be targets of TRPM7. MAP kinases are regulated by TRPM7. In human endothelial cells, downregulation of TRPM7 using a siRNA approach was associated with increased ERK1/2 phosphorylation with no effects on p38MAPK or JNK activation [127]. On the other hand, in HEK293 cells overexpressing TRPM7, ERK1/2 phosphorylation was reduced, while phosphorylation of p38MAPK and JNK was increased [128]. In a rat hepatic stellate cell line (HSC-T6), upregulation of TRPM7 promoted PDGF-induced activation of ERK1/2 and AKT pathways [121]. In mouse cortical astrocytes and in rat VSMCs, TRPM7 siRNA was associated with reduced ERK1/2 phosphorylation [129,130]. Additionally, TRPM7 siRNA reduced activation of Src, p38 MAPK, ERK1/2 and JNK in a breast cancer cell line [131,132].

A regulatory role of TRPM7 in MAPK signaling has also been observed using pharmacological approaches in cancer tissue and cell lines. In glioblastoma cells, naltriben, a pharmacological activator of TRPM7 channel, enhanced ERK1/2 phosphorylation and proliferation, with no effect on the PI3K/AKT pathway (150). Carvacrol, a non-specific inhibitor of TRPM7, suppressed phosphorylation of ERK1/2 and AKT, reducing cell proliferation [133-135]. Thus, there is accumulating evidence supporting a role for TRPM7 in the regulation of MAPK signaling. 
The PI3K/AKT pathway is also affected by TRPM7. In mouse chondrocytes, overexpression of TRPM7 stimulated the AKT pathway, while TRPM7 silencing inhibited AKT signaling [136]. In human osteoblasts, $\mathrm{Mg}^{2+}$-induced increase in mRNA expression of chemotaxis-related genes was attenuated by TRPM7 siRNA and PI3K inhibition, suggesting a link between TRPM7 and PI3K activation mediated by $\mathrm{Mg}^{2+}$.

STAT3 is also modulated by TRPM7. TRPM7 siRNA reduced activation of STAT3 (Tyr705) by affecting phosphorylation of the upstream protein JAK2, a non-receptor tyrosine kinase [137]. Reduced TRPM7 expression was associated with inhibition of Notch activation (Notch1, JAG1, Hey2, and Survivin), involved in angiogenesis and tumor growth mediated by VEGFR and EGFR [138,139]. In breast cancer cells, silencing TRPM7 reduced EGF-induced STAT3 activation and decreased phosphorylation levels of Src, with reduced TRPM7-mediated migration and invasion [131,132].

\section{TRPM7and Kinase Signaling-Pathophysiological Implications}

TRPM7-regulated $\mathrm{Mg}^{2+}$ has versatile biological functions, contributing to all vital cellular processes, including stability of tertiary structures of DNA and RNA, energy metabolism, enzyme activity, signaling, cell cycle progression and cell differentiation [140,141]. The significance of TRPM7 in development and cell viability was demonstrated in mice with global deletion of TRPM7. TRPM7 knockout mice are embryonic lethal and cardiac-targeted knockout of TRPM7 causes impaired embryonic development of the heart [14,142]. The regulatory role of TRPM7 in cell differentiation has been highlighted in various cell types. In mesenchymal stromal cells, TRPM7 mediates shear stress and silencing TRPM7 accelerates osteogenic differentiation [143]. TRPM7 was also shown to mediate differentiation in hepatic cells, lung fibroblasts, dental pulp stem cells and T cells [14,144-146]. Some of these studies investigated underlying mechanisms of the involvement of TRPM7 in cell differentiation. In addition to the contribution of $\mathrm{Ca}^{2+}$ and $\mathrm{Mg}^{2+}$, an interaction between TRPM7 and RTK downstream effectors, including PI3K, AKT and ERK1/2, have been implicated [81,125,145,147-149].

Developmental experiments using zebrafish models of TRPM7 mutants showed abnormal pancreas development, which was associated with increased expression of Suppressor of cytokine signaling (SOCS)-3a, the zebrafish homologue to the human SOCS3, which is part of a classical negative feedback system that influences cytokine signal transduction by reducing activation of JAK-STAT3. $\mathrm{Mg}^{2+}$ supplementation partially attenuated the phenotype [150]. Using genetic and pharmacologic inhibitors, 2-APB or TRPM7-siRNA, it was further shown that TRPM7 modulates effects of PDGF-BB on cell proliferation by regulating activity of cell cycle proteins, including cyclin D1, PCNA and CDK4, through mechanisms that involve tyrosine kinases, ERK1/2 and PI3K [121].

The effects of TRPM7 in pathologic cell differentiation has been intensively investigated in cancer cells, including pancreas, ovary, breast and adenocarcinoma of lungs and prostate [118]. Expression of TRPM7 in these cancers was associated with increased expression of proliferative markers. Epithelial-mesenchymal transition is involved in fibrosis and cancer metastasis and involves EGF activation, effects attenuated by TRPM7 siRNA by mechanisms involving ERK1/2 and STAT3 [132].

Cancer stem cells are cells found within tumors and hematological cancers that have features of normal stem cells, particularly the ability to self-renew and differentiate into multiple cell types [151]. They are rare immortal cells within tumors and are able to induce growth of new tumors and metastases. They are found in numerous tumors and have been considered attractive targets for anti-cancer therapy [152]. Many pathways have been implicated in the regulation of stem cell self-renewal and oncogenesis, including signaling through Notch, Wnt and sonic hedgehog (Shh) [151,152]. In epithelial tumors, epithelial-mesenchymal transition (EMT) seems to be important in cancer stem cell function. Recent evidence indicates that cancer stem cell regulation involves TRPM7-dependent pathways. In lung cancer cells, TRPM7 expression was increased and associated with enhanced SOX2, KLF4, and CD133, Hsp90 $\alpha$, uPA, and MMP2 [153]. TRPM7-silencing inhibited epithelial-to-mesenchymal transition (EMT), suppressed stemness markers and phenotypes, and attenuated activation of the Hsp90 $\alpha / \mathrm{uPA} / \mathrm{MMP} 2$ axis. These effects were ameliorated by waixenicin A, a bioactive extract of soft 
coral, which downregulated TRPM7 and oncogenic markers. Hence, waixenicin A was suggested as an anticancer therapy, by inhibiting lung cancer stem cells through TRPM7 inhibition [153]. In glioma tumorigenesis cancer stem cells, TRPM7 activates JAK2/STAT3- aldehyde dehydrogenase1 (ALDH1) and Notch signaling pathways, contributing to the regulation of cell proliferation, migration and invasion [137]. TRPM7 has also been implicated in epithelial-mesenchymal transition ovarian cancer stem cells, through calcium-related PI3K/AKT oncogenic signaling [154]. In mesenchymal stromal cells (MSCs), TRPM7 senses mechanical stimuli, such as intermittent fluid shear stress and membrane tension, and regulates $\mathrm{Ca}^{2+}$ influx and phosphorylation of signaling kinases, Smad1/5 and p38 MAPK, whereas TRPM7 knockdown decreases MSC proliferation and viability, and induces cell death [143]. Additionally, $\mathrm{Mg}^{2+}$ supplementation promoted osteogenic differentiation through the activation of Notch signaling in MSCs, which was decreased by 2-APB [143,155-157]. In human dental pulp stem cells, silencing TRPM7 inhibited proliferation, migration, and osteogenic differentiation, supporting a role for TRPM7 in the dental pulp repair process [146]. Together, these studies suggest that dysregulation of TRPM7 is important in cancer stem cell regulation and that TRPM7 may be a therapeutic target for oncogenesis [158].

Interactions between RTKs, such as VEGFR and EGFR, TRPM6/7 and $\mathrm{Mg}^{2+}$, have also been implicated in preeclampsia. In a study examining placentas from women with preeclampsia compared to placentas from normotensive women, pre-eclamptic placentas had reduced expression of TRPM6 and TRPM7 [159], which was linked to altered cellular $\mathrm{Mg}^{2+}$ homeostasis. These phenomena were associated with decreased placental VEGF expression in preeclampsia versus normotensive pregnancies, effects normalized by treatment with $\mathrm{MgSO}_{4}$ [160]. Together these findings suggest an important relationship between VEGF, TRPM6/7 and $\mathrm{Mg}^{2+}$ in preeclampsia. This is clinically important because it provides a mechanistic basis for the therapeutic use of $\mathrm{MgSO} 4$ as the drug of choice for preeclampsia [161].

\section{Conclusions and Perspectives}

TRPM7 and TRPM6 are unique proteins characterized by their channel and kinase domains, which differentially regulate cell signaling and function. TRPM6 is mostly expressed in epithelial cells of the kidney and gastrointestinal system, whereas TRPM7 is ubiquitously expressed. In the kidney, TRPM6 and cellular $\mathrm{Mg}^{2+}$ homeostasis are regulated by EGF signaling through EGFR. Inhibition of EGFR signaling impairs TRPM6 function leading to renal $\mathrm{Mg}^{2+}$ wasting and consequent hypomagnesemia in cancer patients treated with EGFR inhibitors [161]. It is still unclear if similar processes influence TRPM7. Experimental studies, mainly in cell models, indicate that VEGFR and EGFR influence TRPM7 activity and $\mathrm{Ca}^{2+}$ and $\mathrm{Mg}^{2+}$ mobilization. Changes in TRPM7 activity and altered $\mathrm{Mg}^{2+}$ homeostasis have a significant effect on tyrosine kinase signaling. Hence, RTKs influence TRPM7, which in turn may influence tyrosine kinase signaling. Most studies have focused on EGFR signaling, but growing evidence indicates that VEGFR and PDGFR also signal through TRPM7. The putative cross-talk between TRPM7 and RTKs has clinical relevance, because inhibitors of RTKs, including VEGFR and EGFR, are increasingly being used to treat cancer and inflammatory diseases. Hence, knowing mechanisms whereby these drugs cause hypomagnesemia is important so that unwanted side effects can be managed in a mechanism-specific manner. The field of TRPM6/7 and RTKs is still immature and further studies are required to unravel the complex interplay between these systems.

Funding: R.M.T. is supported by a British Heart Foundation Award (CH/12/429762). A.C.M. is supported through a Walton Fellowship, University of Glasgow. Z.Z. is funded by China Scholarship Council (201708060309).

Conflicts of Interest: The authors declare no conflict of interest.

\section{References}

1. Clapham, D.E. TRP channels as cellular sensors. Nature 2003, 426, 517-524. [CrossRef] [PubMed]

2. Levitan, I.B.; Cibulsky, S.M. Biochemistry. TRP ion channels-two proteins in one. Science 2001, 293, 1270-1271. [CrossRef] [PubMed] 
3. Duan, J.; Li, Z.; Li, J.; Hulse, R.E.; Santa-Cruz, A.; Valinsky, W.C.; Abiria, S.A.; Krapivinsky, G.; Zhang, J.; Clapham, D.E. Structure of the mammalian TRPM7, a magnesium channel required during embryonic development. Proc. Natl. Acad. Sci. USA 2018, 115, E8201-E8210. [CrossRef] [PubMed]

4. Park, H.S.; Hong, C.; Kim, B.J.; So, I. The Pathophysiologic Roles of TRPM7 Channel. Korean J. Physiol. Pharmacol. 2014, 18, 15-23. [CrossRef] [PubMed]

5. Nadolni, W.; Zierler, S. The Channel-Kinase TRPM7 as Novel Regulator of Immune System Homeostasis. Cells 2018, 7, 109. [CrossRef] [PubMed]

6. Nadler, M.J.; Hermosura, M.C.; Inabe, K.; Perraud, A.L.; Zhu, Q.; Stokes, A.J.; Kurosaki, T.; Kinet, J.P.; Penner, R.; Scharenberg, A.M.; et al. LTRPC7 is a Mg.ATP-regulated divalent cation channel required for cell viability. Nature 2001, 411, 590-595. [CrossRef] [PubMed]

7. He, Y.; Yao, G.; Savoia, C.; Touyz, R.M. Transient receptor potential melastatin 7 ion channels regulate magnesium homeostasis in vascular smooth muscle cells: Role of angiotensin II. Circ. Res. 2005, 96, 207-215. [CrossRef] [PubMed]

8. Gwanyanya, A.; Amuzescu, B.; Zakharov, S.I.; Macianskiene, R.; Sipido, K.R.; Bolotina, V.M.; Vereecke, J.; Mubagwa, K. Magnesium-inhibited, TRPM6/7-like channel in cardiac myocytes: Permeation of divalent cations and pH-mediated regulation. J. Physiol. 2004, 559, 761-776. [CrossRef] [PubMed]

9. Yu, Y.; Chen, S.; Xiao, C.; Jia, Y.; Guo, J.; Jiang, J.; Liu, P. TRPM7 is involved in angiotensin II induced cardiac fibrosis development by mediating calcium and magnesium influx. Cell Calcium 2014, 55, 252-260. [CrossRef] [PubMed]

10. Castiglioni, S.; Cazzaniga, A.; Trapani, V.; Cappadone, C.; Farruggia, G.; Merolle, L.; Wolf, F.I.; Iotti, S.; Maier, J.A. Magnesium homeostasis in colon carcinoma LoVo cells sensitive or resistant to doxorubicin. Sci. Rep. 2015, 5, 16538. [CrossRef] [PubMed]

11. Stritt, S.; Nurden, P.; Favier, R.; Favier, M.; Ferioli, S.; Gotru, S.K.; van Eeuwijk, J.M.; Schulze, H.; Nurden, A.T.; Lambert, M.P.; et al. Defects in TRPM7 channel function deregulate thrombopoiesis through altered cellular $\mathrm{Mg}(2+)$ homeostasis and cytoskeletal architecture. Nat. Commun. 2016, 7, 11097. [CrossRef]

12. Tashiro, M.; Inoue, H.; Konishi, M. Physiological pathway of magnesium influx in rat ventricular myocytes. Biophys. J. 2014, 107, 2049-2058. [CrossRef]

13. Abed, E.; Moreau, R. Importance of melastatin-like transient receptor potential 7 and cations (magnesium, calcium) in human osteoblast-like cell proliferation. Cell Prolif. 2007, 40, 849-865. [CrossRef]

14. Jin, J.; Desai, B.N.; Navarro, B.; Donovan, A.; Andrews, N.C.; Clapham, D.E. Deletion of Trpm7 disrupts embryonic development and thymopoiesis without altering $\mathrm{Mg}^{2+}$ homeostasis. Science 2008, 322, 756-760. [CrossRef]

15. Romagnani, A.; Vettore, V.; Rezzonico-Jost, T.; Hampe, S.; Rottoli, E.; Nadolni, W.; Perotti, M.; Meier, M.A.; Hermanns, C.; Geiger, S.; et al. TRPM7 kinase activity is essential for T cell colonization and alloreactivity in the gut. Nat. Commun. 2017, 8, 1917. [CrossRef]

16. Krapivinsky, G.; Krapivinsky, L.; Manasian, Y.; Clapham, D.E. The TRPM7 chanzyme is cleaved to release a chromatin-modifying kinase. Cell 2014, 157, 1061-1072. [CrossRef]

17. Ryazanova, L.V.; Rondon, L.J.; Zierler, S.; Hu, Z.; Galli, J.; Yamaguchi, T.P.; Mazur, A.; Fleig, A.; Ryazanov, A.G. TRPM7 is essential for $\mathrm{Mg}\left({ }^{2+}\right)$ homeostasis in mammals. Nat. Commun. 2010, 1, 109. [CrossRef]

18. Antunes, T.T.; Callera, G.E.; He, Y.; Yogi, A.; Ryazanov, A.G.; Ryazanova, L.V.; Zhai, A.; Stewart, D.J.; Shrier, A.; Touyz, R.M. Transient Receptor Potential Melastatin 7 Cation Channel Kinase: New Player in Angiotensin II-Induced Hypertension. Hypertension 2016, 67, 763-773. [CrossRef]

19. Kaitsuka, T.; Katagiri, C.; Beesetty, P.; Nakamura, K.; Hourani, S.; Tomizawa, K.; Kozak, J.A.; Matsushita, M. Inactivation of TRPM7 kinase activity does not impair its channel function in mice. Sci. Rep. 2014, 4, 5718. [CrossRef]

20. Krebs, J.; Agellon, L.B.; Michalak, M. Ca $\left({ }^{2+}\right)$ homeostasis and endoplasmic reticulum (ER) stress: An integrated view of calcium signaling. Biochem. Biophys. Res. Commun. 2015, 460, 114-121. [CrossRef]

21. Massullo, P.; Sumoza-Toledo, A.; Bhagat, H.; Partida-Sanchez, S. TRPM channels, calcium and redox sensors during innate immune responses. Semin. Cell Dev. Biol. 2006, 17, 654-666. [CrossRef]

22. Clark, K.; Langeslag, M.; van Leeuwen, B.; Ran, L.; Ryazanov, A.G.; Figdor, C.G.; Moolenaar, W.H.; Jalink, K.; van Leeuwen, F.N. TRPM7, a novel regulator of actomyosin contractility and cell adhesion. EMBO J. 2006, 25, 290-301. [CrossRef] 
23. Schappe, M.S.; Szteyn, K.; Stremska, M.E.; Mendu, S.K.; Downs, T.K.; Seegren, P.V.; Mahoney, M.A.; Dixit, S.; Krupa, J.K.; Stipes, E.J.; et al. Chanzyme TRPM7 Mediates the $\mathrm{Ca}\left({ }^{2+}\right)$ Influx Essential for Lipopolysaccharide-Induced Toll-Like Receptor 4 Endocytosis and Macrophage Activation. Immunity 2018, 48, 59-74. [CrossRef]

24. Faouzi, M.; Kilch, T.; Horgen, F.D.; Fleig, A.; Penner, R. The TRPM7 channel kinase regulates store-operated calcium entry. J. Physiol. 2017, 595, 3165-3180. [CrossRef]

25. Beesetty, P.; Wieczerzak, K.B.; Gibson, J.N.; Kaitsuka, T.; Luu, C.T.; Matsushita, M.; Kozak, J.A. Inactivation of TRPM7 kinase in mice results in enlarged spleens, reduced T-cell proliferation and diminished store-operated calcium entry. Sci. Rep. 2018, 8, 3023. [CrossRef]

26. Inoue, K.; Branigan, D.; Xiong, Z.G. Zinc-induced neurotoxicity mediated by transient receptor potential melastatin 7 channels. J. Biol. Chem. 2010, 285, 7430-7439. [CrossRef]

27. Abiria, S.A.; Krapivinsky, G.; Sah, R.; Santa-Cruz, A.G.; Chaudhuri, D.; Zhang, J.; Adstamongkonkul, P.; DeCaen, P.G.; Clapham, D.E. TRPM7 senses oxidative stress to release $\mathrm{Zn}\left({ }^{2+}\right)$ from unique intracellular vesicles. Proc. Natl. Acad. Sci. USA 2017, 114, E6079-E6088. [CrossRef]

28. Yu, P.; Wang, Q.; Zhang, L.H.; Lee, H.C.; Zhang, L.; Yue, J. A cell permeable NPE caged ADP-ribose for studying TRPM2. PLoS ONE 2012, 7, e51028. [CrossRef]

29. Wagner, T.F.; Drews, A.; Loch, S.; Mohr, F.; Philipp, S.E.; Lambert, S.; Oberwinkler, J. TRPM3 channels provide a regulated influx pathway for zinc in pancreatic beta cells. Pflugers Arch. 2010, 460, 755-765. [CrossRef] [PubMed]

30. Uchida, K.; Tominaga, M. Extracellular zinc ion regulates transient receptor potential melastatin 5 (TRPM5) channel activation through its interaction with a pore loop domain. J. Biol. Chem. 2013, 288, 25950-25955. [CrossRef] [PubMed]

31. Butti, R.; Das, S.; Gunasekaran, V.P.; Yadav, A.S.; Kumar, D.; Kundu, G.C. Receptor tyrosine kinases (RTKs) in breast cancer: Signaling, therapeutic implications and challenges. Mol. Cancer 2018, 17, 34. [CrossRef]

32. Segaliny, A.I.; Tellez-Gabriel, M.; Heymann, M.F.; Heymann, D. Receptor tyrosine kinases: Characterisation, mechanism of action and therapeutic interests for bone cancers. J. Bone Oncol. 2015, 4, 1-12. [CrossRef]

33. Thebault, S.; Alexander, R.T.; Tiel Groenestege, W.M.; Hoenderop, J.G.; Bindels, R.J. EGF increases TRPM6 activity and surface expression. J. Am. Soc. Nephrol. 2009, 20, 78-85. [CrossRef]

34. Groenestege, W.M.; Thebault, S.; van der Wijst, J.; van den Berg, D.; Janssen, R.; Tejpar, S.; van den Heuvel, L.P.; van Cutsem, E.; Hoenderop, J.G.; Knoers, N.V.; et al. Impaired basolateral sorting of pro-EGF causes isolated recessive renal hypomagnesemia. J. Clin. Investig. 2007, 117, 2260-2267. [CrossRef]

35. Dimke, H.; van der Wijst, J.; Alexander, T.R.; Meijer, I.M.; Mulder, G.M.; van Goor, H.; Tejpar, S.; Hoenderop, J.G.; Bindels, R.J. Effects of the EGFR Inhibitor Erlotinib on Magnesium Handling. J. Am. Soc. Nephrol. 2010, 21, 1309-1316. [CrossRef]

36. Trapani, V.; Arduini, D.; Luongo, F.; Wolf, F.I. EGF stimulates $\mathrm{Mg}\left({ }^{2+}\right)$ influx in mammary epithelial cells. Biochem. Biophys. Res. Commun. 2014, 454, 572-575. [CrossRef]

37. Hofheinz, R.D.; Segaert, S.; Safont, M.J.; Demonty, G.; Prenen, H. Management of adverse events during treatment of gastrointestinal cancers with epidermal growth factor inhibitors. Crit. Rev. Oncol. Hematol. 2017, 114, 102-113. [CrossRef]

38. Middelbeek, J.; Clark, K.; Venselaar, H.; Huynen, M.A.; van Leeuwen, F.N. The alpha-kinase family: An exceptional branch on the protein kinase tree. Cell Mol. Life Sci. 2010, 67, 875-890. [CrossRef]

39. Yamaguchi, H.; Matsushita, M.; Nairn, A.C.; Kuriyan, J. Crystal structure of the atypical protein kinase domain of a TRP channel with phosphotransferase activity. Mol. Cell 2001, 7, 1047-1057. [CrossRef]

40. Kim, T.Y.; Shin, S.K.; Song, M.Y.; Lee, J.E.; Park, K.S. Identification of the phosphorylation sites on intact TRPM7 channels from mammalian cells. Biochem. Biophys. Res. Commun. 2012, 417, 1030-1034. [CrossRef]

41. Clark, K.; Middelbeek, J.; Morrice, N.A.; Figdor, C.G.; Lasonder, E.; van Leeuwen, F.N. Massive autophosphorylation of the Ser/Thr-rich domain controls protein kinase activity of TRPM6 and TRPM7. PLoS ONE 2008, 3, e1876. [CrossRef] [PubMed]

42. Ryazanova, L.V.; Dorovkov, M.V.; Ansari, A.; Ryazanov, A.G. Characterization of the protein kinase activity of TRPM7/ChaK1, a protein kinase fused to the transient receptor potential ion channel. J. Biol. Chem. 2004, 279, 3708-3716. [CrossRef] [PubMed] 
43. Clark, K.; Middelbeek, J.; Lasonder, E.; Dulyaninova, N.G.; Morrice, N.A.; Ryazanov, A.G.; Bresnick, A.R.; Figdor, C.G.; van Leeuwen, F.N. TRPM7 regulates myosin IIA filament stability and protein localization by heavy chain phosphorylation. J. Mol. Biol. 2008, 378, 790-803. [CrossRef]

44. Perraud, A.L.; Zhao, X.; Ryazanov, A.G.; Schmitz, C. The channel-kinase TRPM7 regulates phosphorylation of the translational factor eEF2 via eEF2-k. Cell Signal 2011, 23, 586-593. [CrossRef]

45. Deason-Towne, F.; Perraud, A.L.; Schmitz, C. Identification of Ser/Thr phosphorylation sites in the C2-domain of phospholipase C gamma2 (PLCgamma2) using TRPM7-kinase. Cell Signal 2012, 24, 2070-2075. [CrossRef]

46. Desai, B.N.; Krapivinsky, G.; Navarro, B.; Krapivinsky, L.; Carter, B.C.; Febvay, S.; Delling, M.; Penumaka, A.; Ramsey, I.S.; Manasian, Y.; et al. Cleavage of TRPM7 releases the kinase domain from the ion channel and regulates its participation in Fas-induced apoptosis. Dev. Cell 2012, 22, 1149-1162. [CrossRef]

47. Krapivinsky, G.; Krapivinsky, L.; Renthal, N.E.; Santa-Cruz, A.; Manasian, Y.; Clapham, D.E. Histone phosphorylation by TRPM6's cleaved kinase attenuates adjacent arginine methylation to regulate gene expression. Proc. Natl. Acad. Sci. USA 2017, 114, E7092-E7100. [CrossRef]

48. Matsushita, M.; Kozak, J.A.; Shimizu, Y.; McLachlin, D.T.; Yamaguchi, H.; Wei, F.Y.; Tomizawa, K.; Matsui, H.; Chait, B.T.; Cahalan, M.D.; et al. Channel function is dissociated from the intrinsic kinase activity and autophosphorylation of TRPM7/ChaK1. J. Biol. Chem. 2005, 280, 20793-20803. [CrossRef] [PubMed]

49. Schmitz, C.; Perraud, A.L.; Johnson, C.O.; Inabe, K.; Smith, M.K.; Penner, R.; Kurosaki, T.; Fleig, A.; Scharenberg, A.M. Regulation of vertebrate cellular $\mathrm{Mg}^{2+}$ homeostasis by TRPM7. Cell 2003, 114, 191-200. [CrossRef]

50. Demeuse, P.; Penner, R.; Fleig, A. TRPM7 channel is regulated by magnesium nucleotides via its kinase domain. J. Gen. Physiol. 2006, 127, 421-434. [CrossRef]

51. Yu, H.; Zhang, Z.; Lis, A.; Penner, R.; Fleig, A. TRPM7 is regulated by halides through its kinase domain. Cell Mol. Life Sci. 2013, 70, 2757-2771. [CrossRef]

52. Takezawa, R.; Schmitz, C.; Demeuse, P.; Scharenberg, A.M.; Penner, R.; Fleig, A. Receptor-mediated regulation of the TRPM7 channel through its endogenous protein kinase domain. Proc. Natl. Acad. Sci. USA 2004, 101, 6009-6014. [CrossRef]

53. Chubanov, V.; Ferioli, S.; Wisnowsky, A.; Simmons, D.G.; Leitzinger, C.; Einer, C.; Jonas, W.; Shymkiv, Y.; Bartsch, H.; Braun, A.; et al. Epithelial magnesium transport by TRPM6 is essential for prenatal development and adult survival. Elife 2016, 5, e20914. [CrossRef]

54. Li, M.; Du, J.; Jiang, J.; Ratzan, W.; Su, L.T.; Runnels, L.W.; Yue, L. Molecular determinants of $\mathrm{Mg}^{2+}$ and Ca ${ }^{2+}$ permeability and pH sensitivity in TRPM6 and TRPM7. J. Biol. Chem. 2007, 282, 25817-25830. [CrossRef]

55. Krapivinsky, G.; Mochida, S.; Krapivinsky, L.; Cibulsky, S.M.; Clapham, D.E. The TRPM7 ion channel functions in cholinergic synaptic vesicles and affects transmitter release. Neuron 2006, 52, 485-496. [CrossRef]

56. Hermosura, M.C.; Nayakanti, H.; Dorovkov, M.V.; Calderon, F.R.; Ryazanov, A.G.; Haymer, D.S.; Garruto, R.M. A TRPM7 variant shows altered sensitivity to magnesium that may contribute to the pathogenesis of two Guamanian neurodegenerative disorders. Proc. Natl. Acad. Sci. USA 2005, 102, 11510-11515. [CrossRef]

57. Crawley, S.W.; Cote, G.P. Identification of dimer interactions required for the catalytic activity of the TRPM7 alpha-kinase domain. Biochem. J. 2009, 420, 115-122. [CrossRef]

58. Su, L.T.; Agapito, M.A.; Li, M.; Simonson, W.T.; Huttenlocher, A.; Habas, R.; Yue, L.; Runnels, L.W. TRPM7 regulates cell adhesion by controlling the calcium-dependent protease calpain. J. Biol. Chem. 2006, 281, 11260-11270. [CrossRef]

59. Ryazanova, L.V.; Hu, Z.; Suzuki, S.; Chubanov, V.; Fleig, A.; Ryazanov, A.G. Elucidating the role of the TRPM7 alpha-kinase: TRPM7 kinase inactivation leads to magnesium deprivation resistance phenotype in mice. Sci. Rep. 2014, 4, 7599. [CrossRef]

60. Chubanov, V.; Waldegger, S.; Mederos y Schnitzler, M.; Vitzthum, H.; Sassen, M.C.; Seyberth, H.W.; Konrad, M.; Gudermann, T. Disruption of TRPM6/TRPM7 complex formation by a mutation in the TRPM6 gene causes hypomagnesemia with secondary hypocalcemia. Proc. Natl. Acad. Sci. USA 2004, 101, 2894-2899. [CrossRef]

61. Cai, N.; Bai, Z.; Nanda, V.; Runnels, L.W. Mass Spectrometric Analysis of TRPM6 and TRPM7 Phosphorylation Reveals Regulatory Mechanisms of the Channel-Kinases. Sci. Rep. 2017, 7, 42739. [CrossRef]

62. Deason-Towne, F.; Perraud, A.L.; Schmitz, C. The $\mathrm{Mg}^{2+}$ transporter MagT1 partially rescues cell growth and $\mathrm{Mg}^{2+}$ uptake in cells lacking the channel-kinase TRPM7. FEBS Lett. 2011, 585, 2275-2278. [CrossRef] [PubMed] 
63. Cazzaniga, A.; Moscheni, C.; Trapani, V.; Wolf, F.I.; Farruggia, G.; Sargenti, A.; Iotti, S.; Maier, J.A.; Castiglioni, S. The different expression of TRPM7 and MagT1 impacts on the proliferation of colon carcinoma cells sensitive or resistant to doxorubicin. Sci. Rep. 2017, 7, 40538. [CrossRef] [PubMed]

64. Goytain, A.; Quamme, G.A. Identification and characterization of a novel mammalian $\mathrm{Mg}^{2+}$ transporter with channel-like properties. BMC Genom. 2005, 6, 48. [CrossRef]

65. Maret, W. Zinc biochemistry: From a single zinc enzyme to a key element of life. Adv. Nutr. 2013, 4, 82-91. [CrossRef]

66. Long, S.; Romani, A.M. Role of Cellular Magnesium in Human Diseases. Austin J. Nutr. Food Sci. 2014, 2,1051 .

67. Ikari, A.; Sawada, H.; Sanada, A.; Tonegawa, C.; Yamazaki, Y.; Sugatani, J. Magnesium deficiency suppresses cell cycle progression mediated by increase in transcriptional activity of p21(Cip1) and p27(Kip1) in renal epithelial NRK-52E cells. J. Cell Biochem. 2011, 112, 3563-3572. [CrossRef]

68. MacDonald, R.S. The role of zinc in growth and cell proliferation. J. Nutr. 2000, 130, 1500S-1508S. [CrossRef]

69. Capiod, T. Cell proliferation, calcium influx and calcium channels. Biochimie 2011, 93, 2075-2079. [CrossRef]

70. Resende, R.R.; Andrade, L.M.; Oliveira, A.G.; Guimaraes, E.S.; Guatimosim, S.; Leite, M.F. Nucleoplasmic calcium signaling and cell proliferation: Calcium signaling in the nucleus. Cell Commun. Signal 2013, 11, 14. [CrossRef]

71. Ni, H.M.; Baty, C.J.; Li, N.; Ding, W.X.; Gao, W.; Li, M.; Chen, X.; Ma, J.; Michalopoulos, G.K.; Yin, X.M. Bid agonist regulates murine hepatocyte proliferation by controlling endoplasmic reticulum calcium homeostasis. Hepatology 2010, 52, 338-348. [CrossRef]

72. Munaron, L. Calcium signalling and control of cell proliferation by tyrosine kinase receptors (review). Int J. Mol. Med. 2002, 10, 671-676. [CrossRef]

73. Paxton, R.; Ye, L. Regulation of heart insulin receptor tyrosine kinase activity by magnesium and spermine. Mol. Cell Biochem. 2005, 277, 7-17. [CrossRef]

74. Grubbs, R.D. Effect of epidermal growth factor on magnesium homeostasis in BC3H1 myocytes. Am. J. Physiol. 1991, 260, C1158-C1164. [CrossRef] [PubMed]

75. Lemmon, M.A.; Schlessinger, J. Cell signaling by receptor tyrosine kinases. Cell 2010, 141, 1117-1134. [CrossRef] [PubMed]

76. Valinsky, W.C.; Jolly, A.; Miquel, P.; Touyz, R.M.; Shrier, A. Aldosterone Upregulates Transient Receptor Potential Melastatin 7 (TRPM7). J. Biol. Chem. 2016, 291, 20163-20172. [CrossRef]

77. Yogi, A.; Callera, G.E.; O'Connor, S.E.; He, Y.; Correa, J.W.; Tostes, R.C.; Mazur, A.; Touyz, R.M. Dysregulation of renal transient receptor potential melastatin 6/7 but not paracellin-1 in aldosterone-induced hypertension and kidney damage in a model of hereditary hypomagnesemia. J. Hypertens. 2011, 29, 1400-1410. [CrossRef] [PubMed]

78. Callera, G.E.; He, Y.; Yogi, A.; Montezano, A.C.; Paravicini, T.; Yao, G.; Touyz, R.M. Regulation of the novel $\mathrm{Mg}^{2+}$ transporter transient receptor potential melastatin 7 (TRPM7) cation channel by bradykinin in vascular smooth muscle cells. J. Hypertens. 2009, 27, 155-166. [CrossRef]

79. Touyz, R.M.; He, Y.; Montezano, A.C.; Yao, G.; Chubanov, V.; Gudermann, T.; Callera, G.E. Differential regulation of transient receptor potential melastatin 6 and 7 cation channels by ANG II in vascular smooth muscle cells from spontaneously hypertensive rats. Am. J. Physiol. Regul. Integr. Comp. Physiol. 2006, 290, R73-R78. [CrossRef]

80. Yogi, A.; Callera, G.E.; Antunes, T.T.; Tostes, R.C.; Touyz, R.M. Transient receptor potential melastatin 7 (TRPM7) cation channels, magnesium and the vascular system in hypertension. Circ. J. Off. J. Jpn. Circ. Soc. 2011, 75, 237-245. [CrossRef]

81. Montezano, A.C.; Zimmerman, D.; Yusuf, H.; Burger, D.; Chignalia, A.Z.; Wadhera, V.; van Leeuwen, F.N.; Touyz, R.M. Vascular smooth muscle cell differentiation to an osteogenic phenotype involves TRPM7 modulation by magnesium. Hypertension 2010, 56, 453-462. [CrossRef] [PubMed]

82. Kim, B.M.; Yoon, W.; Shim, J.H.; Jung, H.; Lim, J.H.; Choi, H.J.; Seo, M.; Lee, T.H.; Min, S.H. Role of Protein Kinases and Their Inhibitors in Radiation Response of Tumor Cells. Curr. Pharm. Des. 2017, 23, 4259-4280. [CrossRef]

83. Schwartz, P.A.; Murray, B.W. Protein kinase biochemistry and drug discovery. Bioor.g Chem. 2011, 39, $192-210$. [CrossRef] 
84. Hubbard, S.R.; Miller, W.T. Receptor tyrosine kinases: Mechanisms of activation and signaling. Curr. Opin. Cell Biol. 2007, 19, 117-123. [CrossRef]

85. Du, Z.; Lovly, C.M. Mechanisms of receptor tyrosine kinase activation in cancer. Mol. Cancer 2018, 17, 58. [CrossRef]

86. Lee, J.; Miyazaki, M.; Romeo, G.R.; Shoelson, S.E. Insulin receptor activation with transmembrane domain ligands. J. Biol. Chem. 2014, 289, 19769-19777. [CrossRef]

87. Niu, X.L.; Peters, K.G.; Kontos, C.D. Deletion of the carboxyl terminus of Tie2 enhances kinase activity, signaling, and function. Evidence for an autoinhibitory mechanism. J. Biol. Chem. 2002, 277, 31768-31773. [CrossRef]

88. Hubbard, S.R. Autoinhibitory mechanisms in receptor tyrosine kinases. Front. Biosci. 2002, 7, d330-d340. [CrossRef] [PubMed]

89. Roskoski, R., Jr. Src protein-tyrosine kinase structure, mechanism, and small molecule inhibitors. Pharmacol. Res. 2015, 94, 9-25. [CrossRef] [PubMed]

90. Zheng, J.; Knighton, D.R.; Ten Eyck, L.F.; Karlsson, R.; Xuong, N.; Taylor, S.S.; Sowadski, J.M. Crystal structure of the catalytic subunit of cAMP-dependent protein kinase complexed with magnesium-ATP and peptide inhibitor. Biochemistry 1993, 32, 2154-2161. [CrossRef]

91. Bastidas, A.C.; Deal, M.S.; Steichen, J.M.; Guo, Y.; Wu, J.; Taylor, S.S. Phosphoryl transfer by protein kinase A is captured in a crystal lattice. J. Am. Chem. Soc. 2013, 135, 4788-4798. [CrossRef]

92. Hadari, Y.R.; Gotoh, N.; Kouhara, H.; Lax, I.; Schlessinger, J. Critical role for the docking-protein FRS2 alpha in FGF receptor-mediated signal transduction pathways. Proc. Natl. Acad. Sci. USA 2001, 98, 8578-8583. [CrossRef]

93. Fraser, J.; Cabodevilla, A.G.; Simpson, J.; Gammoh, N. Interplay of autophagy, receptor tyrosine kinase signalling and endocytic trafficking. Essays Biochem. 2017, 61, 597-607. [CrossRef]

94. Arkun, Y.; Yasemi, M. Dynamics and control of the ERK signaling pathway: Sensitivity, bistability, and oscillations. PLoS ONE 2018, 13, e0195513. [CrossRef]

95. Soares-Silva, M.; Diniz, F.F.; Gomes, G.N.; Bahia, D. The Mitogen-Activated Protein Kinase (MAPK) Pathway: Role in Immune Evasion by Trypanosomatids. Front. Microbiol. 2016, 7, 183. [CrossRef]

96. Annenkov, A. Receptor tyrosine kinase (RTK) signalling in the control of neural stem and progenitor cell (NSPC) development. Mol. Neurobiol. 2014, 49, 440-471. [CrossRef]

97. Papadimitrakopoulou, V. Development of PI3K/AKT/mTOR pathway inhibitors and their application in personalized therapy for non-small-cell lung cancer. J. Thorac. Oncol. 2012, 7, 1315-1326. [CrossRef]

98. Liu, P.; Cheng, H.; Roberts, T.M.; Zhao, J.J. Targeting the phosphoinositide 3-kinase pathway in cancer. Nat. Rev. Drug Discov. 2009, 8, 627-644. [CrossRef]

99. Paquette, M.; El-Houjeiri, L.; Pause, A. mTOR Pathways in Cancer and Autophagy. Cancers (Basel) 2018, 10, 18. [CrossRef]

100. Chang, L.; Graham, P.H.; Ni, J.; Hao, J.; Bucci, J.; Cozzi, P.J.; Li, Y. Targeting PI3K/Akt/mTOR signaling pathway in the treatment of prostate cancer radioresistance. Crit. Rev. Oncol. Hematol. 2015, 96, 507-517. [CrossRef]

101. Rhee, S.G. Regulation of phosphoinositide-specific phospholipase C. Annu. Rev. Biochem. 2001, 70, $281-312$. [CrossRef]

102. Yang, Y.R.; Follo, M.Y.; Cocco, L.; Suh, P.G. The physiological roles of primary phospholipase C. Adv. Biol. Regul. 2013, 53, 232-241. [CrossRef] [PubMed]

103. Putney, J.W.; Tomita, T. Phospholipase C signaling and calcium influx. Adv. Biol. Regul. 2012, 52, $152-164$. [CrossRef] [PubMed]

104. Mikoshiba, K. IP3 receptor/Ca ${ }^{2+}$ channel: From discovery to new signaling concepts. J. Neurochem. 2007, 102, 1426-1446. [CrossRef] [PubMed]

105. Fukami, K.; Inanobe, S.; Kanemaru, K.; Nakamura, Y. Phospholipase C is a key enzyme regulating intracellular calcium and modulating the phosphoinositide balance. Prog. Lipid Res. 2010, 49, 429-437. [CrossRef]

106. Zhu, M.; Leung, C.Y.; Shahbazi, M.N.; Zernicka-Goetz, M. Actomyosin polarisation through PLC-PKC triggers symmetry breaking of the mouse embryo. Nat. Commun. 2017, 8, 921. [CrossRef]

107. Chen, J.; Zheng, D.; Cui, H.; Liu, S.; Zhang, L.; Liu, C. Roles and mechanisms of TRPC3 and the PLCgamma/PKC/CPI-17 signaling pathway in regulating parturition. Mol. Med. Rep. 2018, 17, 898-910. 
108. Yu, M.; Chen, Y.; Zeng, H.; Zheng, Y.; Fu, G.; Zhu, W.; Broeckel, U.; Aggarwal, P.; Turner, A.; Neale, G.; et al. PLCgamma-dependent mTOR signalling controls IL-7-mediated early B cell development. Nat. Commun. 2017, 8, 1457. [CrossRef] [PubMed]

109. Harrison, D.A. The Jak/STAT pathway. Cold Spring Harb. Perspect. Biol. 2012, 4, a011205. [CrossRef]

110. Izzedine, H.; Perazella, M.A. Adverse kidney effects of epidermal growth factor receptor inhibitors. Nephrol. Dial. Transpl. 2017, 32, 1089-1097. [CrossRef] [PubMed]

111. Robinson, E.S.; Khankin, E.V.; Karumanchi, S.A.; Humphreys, B.D. Hypertension induced by vascular endothelial growth factor signaling pathway inhibition: Mechanisms and potential use as a biomarker. Semin. Nephrol. 2010, 30, 591-601. [CrossRef]

112. Mouhayar, E.; Salahudeen, A. Hypertension in cancer patients. Tex. Heart Inst. J. 2011, 38, $263-265$.

113. Fakih, M.; Vincent, M. Adverse events associated with anti-EGFR therapies for the treatment of metastatic colorectal cancer. Curr. Oncol. 2010, 17 (Suppl. 1), S18-S30. [CrossRef]

114. Cosmai, L.; Gallieni, M.; Porta, C. Renal toxicity of anticancer agents targeting HER2 and EGFR. J. Nephrol. 2015, 28, 647-657. [CrossRef]

115. Hong, B.Z.; Kang, H.S.; So, J.N.; Kim, H.N.; Park, S.A.; Kim, S.J.; Kim, K.R.; Kwak, Y.G. Vascular endothelial growth factor increases the intracellular magnesium. Biochem. Biophys. Res. Commun. 2006, 347, 496-501. [CrossRef]

116. Jalkanen, R.; Pronicka, E.; Tyynismaa, H.; Hanauer, A.; Walder, R.; Alitalo, T. Genetic background of HSH in three Polish families and a patient with an X;9 translocation. Eur. J. Hum. Genet. 2006, 14, 55-62. [CrossRef]

117. Runnels, L.W.; Yue, L.; Clapham, D.E. The TRPM7 channel is inactivated by PIP(2) hydrolysis. Nat. Cell Biol. 2002, 4, 329-336. [CrossRef]

118. Gao, H.; Chen, X.; Du, X.; Guan, B.; Liu, Y.; Zhang, H. EGF enhances the migration of cancer cells by up-regulation of TRPM7. Cell Calcium 2011, 50, 559-568. [CrossRef]

119. Tian, S.L.; Jiang, H.; Zeng, Y.; Li, L.L.; Shi, J. NGF-induced reduction of an outward-rectifying TRPM7-like current in rat CA1 hippocampal neurons. Neurosci. Lett. 2007, 419, 93-98. [CrossRef]

120. Jiang, H.; Tian, S.L.; Zeng, Y.; Li, L.L.; Shi, J. TrkA pathway(s) is involved in regulation of TRPM7 expression in hippocampal neurons subjected to ischemic-reperfusion and oxygen-glucose deprivation. Brain Res. Bull. 2008, 76, 124-130. [CrossRef]

121. Fang, L.; Zhan, S.; Huang, C.; Cheng, X.; Lv, X.; Si, H.; Li, J. TRPM7 channel regulates PDGF-BB-induced proliferation of hepatic stellate cells via PI3K and ERK pathways. Toxicol. Appl. Pharmacol. 2013, 272, 713-725. [CrossRef]

122. Langeslag, M.; Clark, K.; Moolenaar, W.H.; van Leeuwen, F.N.; Jalink, K. Activation of TRPM7 channels by phospholipase C-coupled receptor agonists. J. Biol. Chem. 2007, 282, 232-239. [CrossRef]

123. Sun, Y.; Sukumaran, P.; Varma, A.; Derry, S.; Sahmoun, A.E.; Singh, B.B. Cholesterol-induced activation of TRPM7 regulates cell proliferation, migration, and viability of human prostate cells. Biochim. Biophys. Acta 2014, 1843, 1839-1850. [CrossRef]

124. Zhang, Z.; Wang, M.; Fan, X.H.; Chen, J.H.; Guan, Y.Y.; Tang, Y.B. Upregulation of TRPM7 channels by angiotensin II triggers phenotypic switching of vascular smooth muscle cells of ascending aorta. Circ. Res. 2012, 111, 1137-1146. [CrossRef]

125. Zhang, K.; Zhang, Y.; Feng, W.; Chen, R.; Chen, J.; Touyz, R.M.; Wang, J.; Huang, H. Interleukin-18 Enhances Vascular Calcification and Osteogenic Differentiation of Vascular Smooth Muscle Cells Through TRPM7 Activation. Arterioscler. Thromb. Vasc. Biol. 2017, 37, 1933-1943. [CrossRef]

126. Liu, A.; Zhao, F.; Wang, J.; Zhao, Y.; Luo, Z.; Gao, Y.; Shi, J. Regulation of TRPM7 Function by IL-6 through the JAK2-STAT3 Signaling Pathway. PLOS ONE 2016, 11, e0152120. [CrossRef]

127. Inoue, K.; Xiong, Z.G. Silencing TRPM7 promotes growth/proliferation and nitric oxide production of vascular endothelial cells via the ERK pathway. Cardiovasc. Res. 2009, 83, 547-557. [CrossRef]

128. Su, L.T.; Chen, H.C.; Gonzalez-Pagan, O.; Overton, J.D.; Xie, J.; Yue, L.; Runnels, L.W. TRPM7 activates $\mathrm{m}$-calpain by stress-dependent stimulation of p38 MAPK and c-Jun N-terminal kinase. J. Mol. Biol. 2010, 396, 858-869. [CrossRef]

129. Zeng, Z.; Leng, T.; Feng, X.; Sun, H.; Inoue, K.; Zhu, L.; Xiong, Z.G. Silencing TRPM7 in mouse cortical astrocytes impairs cell proliferation and migration via ERK and JNK signaling pathways. PLoS ONE 2015, 10, e0119912. [CrossRef] 
130. Lin, J.; Zhou, S.; Zhao, T.; Ju, T.; Zhang, L. TRPM7 channel regulates ox-LDL-induced proliferation and migration of vascular smooth muscle cells via MEK-ERK pathways. FEBS Lett. 2016, 590, 520-532. [CrossRef]

131. Meng, X.; Cai, C.; Wu, J.; Cai, S.; Ye, C.; Chen, H.; Yang, Z.; Zeng, H.; Shen, Q.; Zou, F. TRPM7 mediates breast cancer cell migration and invasion through the MAPK pathway. Cancer Lett. 2013, 333, 96-102. [CrossRef]

132. Davis, F.M.; Azimi, I.; Faville, R.A.; Peters, A.A.; Jalink, K.; Putney, J.W., Jr.; Goodhill, G.J.; Thompson, E.W.; Roberts-Thomson, S.J.; Monteith, G.R. Induction of epithelial-mesenchymal transition (EMT) in breast cancer cells is calcium signal dependent. Oncogene 2014, 33, 2307-2316. [CrossRef]

133. Wong, R.; Turlova, E.; Feng, Z.P.; Rutka, J.T.; Sun, H.S. Activation of TRPM7 by naltriben enhances migration and invasion of glioblastoma cells. Oncotarget 2017, 8, 11239-11248. [CrossRef]

134. Chen, W.L.; Barszczyk, A.; Turlova, E.; Deurloo, M.; Liu, B.; Yang, B.B.; Rutka, J.T.; Feng, Z.P.; Sun, H.S. Inhibition of TRPM7 by carvacrol suppresses glioblastoma cell proliferation, migration and invasion. Oncotarget 2015, 6, 16321-16340. [CrossRef]

135. Luo, Y.; Wu, J.Y.; Lu, M.H.; Shi, Z.; Na, N.; Di, J.M. Carvacrol Alleviates Prostate Cancer Cell Proliferation, Migration, and Invasion through Regulation of PI3K/Akt and MAPK Signaling Pathways. Oxid. Med. Cell. Longev. 2016, 2016, 1469693. [CrossRef]

136. Lu, D.; Qu, J.; Sun, L.; Li, Q.; Ling, H.; Yang, N.; Ma, T.; Wang, Q.; Li, M.; Zhang, K.; et al. $\mathrm{Ca}^{2+} / \mathrm{Mg}^{2+}$ homeostasisrelated TRPM7 channel mediates chondrocyte hypertrophy via regulation of the PI3KAkt signaling pathway. Mol. Med. Rep. 2017, 16, 5699-5705. [CrossRef]

137. Liu, M.; Inoue, K.; Leng, T.; Guo, S.; Xiong, Z.G. TRPM7 channels regulate glioma stem cell through STAT3 and Notch signaling pathways. Cell Signal 2014, 26, 2773-2781. [CrossRef]

138. Saltarella, I.; Frassanito, M.A.; Lamanuzzi, A.; Brevi, A.; Leone, P.; Desantis, V.; Di Marzo, L.; Bellone, M.; Derudas, D.; Ribatti, D.; et al. Homotypic and Heterotypic Activation of the Notch Pathway in Multiple Myeloma-Enhanced Angiogenesis: A Novel Therapeutic Target? Neoplasia 2019, 21, 93-105. [CrossRef]

139. Wang, W.M.; Zhao, Z.L.; Ma, S.R.; Yu, G.T.; Liu, B.; Zhang, L.; Zhang, W.F.; Kulkarni, A.B.; Sun, Z.J.; Zhao, Y.F. Epidermal growth factor receptor inhibition reduces angiogenesis via hypoxia-inducible factor-1alpha and Notch1 in head neck squamous cell carcinoma. PLoS ONE 2015, 10, e0119723.

140. Romani, A.M. Cellular magnesium homeostasis. Arch. Biochem. Biophys. 2011, 512, 1-23. [CrossRef]

141. Al Alawi, A.M.; Majoni, S.W.; Falhammar, H. Magnesium and Human Health: Perspectives and Research Directions. Int. J. Endocrinol. 2018, 2018, 9041694. [CrossRef]

142. Jin, J.; Wu, L.J.; Jun, J.; Cheng, X.; Xu, H.; Andrews, N.C.; Clapham, D.E. The channel kinase, TRPM7, is required for early embryonic development. Proc. Natl. Acad. Sci. USA 2012, 109, E225-E233. [CrossRef]

143. Liu, Y.S.; Liu, Y.A.; Huang, C.J.; Yen, M.H.; Tseng, C.T.; Chien, S.; Lee, O.K. Mechanosensitive TRPM7 mediates shear stress and modulates osteogenic differentiation of mesenchymal stromal cells through Osterix pathway. Sci. Rep. 2015, 5, 16522. [CrossRef]

144. Ogunrinde, A.; Pereira, R.D.; Beaton, N.; Lam, D.H.; Whetstone, C.; Hill, C.E. Hepatocellular differentiation status is characterized by distinct subnuclear localization and form of the chanzyme TRPM7. Differentiation 2017, 96, 15-25. [CrossRef]

145. Yu, M.; Huang, C.; Huang, Y.; Wu, X.; Li, X.; Li, J. Inhibition of TRPM7 channels prevents proliferation and differentiation of human lung fibroblasts. Inflamm. Res. 2013, 62, 961-970. [CrossRef]

146. Cui, L.; Xu, S.M.; Ma, D.D.; Wu, B.L. The effect of TRPM7 suppression on the proliferation, migration and osteogenic differentiation of human dental pulp stem cells. Int. Endod. J. 2014, 47, 583-593. [CrossRef]

147. Zhang, X.; Zu, H.; Zhao, D.; Yang, K.; Tian, S.; Yu, X.; Lu, F.; Liu, B.; Yu, X.; Wang, B.; et al. Ion channel functional protein kinase TRPM7 regulates $\mathrm{Mg}$ ions to promote the osteoinduction of human osteoblast via PI3K pathway: In vitro simulation of the bone-repairing effect of $\mathrm{Mg}$-based alloy implant. Acta Biomater. 2017, 63, 369-382. [CrossRef]

148. Takahashi, K.; Umebayashi, C.; Numata, T.; Honda, A.; Ichikawa, J.; Hu, Y.; Yamaura, K.; Inoue, R. TRPM7-mediated spontaneous $\mathrm{Ca}\left({ }^{2+}\right)$ entry regulates the proliferation and differentiation of human leukemia cell line K562. Physiol. Rep. 2018, 6, e13796. [CrossRef]

149. Yang, M.; Fang, J.; Liu, Q.; Wang, Y.; Zhang, Z. Role of ROS-TRPM7-ERK1/2 axis in high concentration glucose-mediated proliferation and phenotype switching of rat aortic vascular smooth muscle cells. Biochem. Biophys. Res. Commun. 2017, 494, 526-533. [CrossRef] 
150. Yee, N.S.; Zhou, W.; Liang, I.C. Transient receptor potential ion channel Trpm7 regulates exocrine pancreatic epithelial proliferation by $\mathrm{Mg}^{2+}$-sensitive Socs3a signaling in development and cancer. Dis. Model. Mech. 2011, 4, 240-254. [CrossRef] [PubMed]

151. Batlle, E.; Clevers, H. Cancer stem cells revisited. Nat. Med. 2017, 23, 1124-1134. [CrossRef]

152. Reya, T.; Morrison, S.J.; Clarke, M.F.; Weissman, I.L. Stem cells, cancer, and cancer stem cells. Nature 2001, 414, 105-111. [CrossRef]

153. Liu, K.; Xu, S.H.; Chen, Z.; Zeng, Q.X.; Li, Z.J.; Chen, Z.M. TRPM7 overexpression enhances the cancer stem cell-like and metastatic phenotypes of lung cancer through modulation of the Hsp90alpha/uPA/MMP2 signaling pathway. BMC Cancer 2018, 18, 1167. [CrossRef] [PubMed]

154. Liu, L.; Wu, N.; Wang, Y.; Zhang, X.; Xia, B.; Tang, J.; Cai, J.; Zhao, Z.; Liao, Q.; Wang, J. TRPM7 promotes the epithelial-mesenchymal transition in ovarian cancer through the calcium-related PI3K / AKT oncogenic signaling. J. Exp. Clin. Cancer Res. 2019, 38, 106. [CrossRef]

155. Xiao, E.; Yang, H.Q.; Gan, Y.H.; Duan, D.H.; He, L.H.; Guo, Y.; Wang, S.Q.; Zhang, Y. Brief reports: TRPM7 Senses mechanical stimulation inducing osteogenesis in human bone marrow mesenchymal stem cells. Stem Cells 2015, 33, 615-621. [CrossRef]

156. Cheng, H.; Feng, J.M.; Figueiredo, M.L.; Zhang, H.; Nelson, P.L.; Marigo, V.; Beck, A. Transient receptor potential melastatin type 7 channel is critical for the survival of bone marrow derived mesenchymal stem cells. Stem Cells Dev. 2010, 19, 1393-1403. [CrossRef]

157. Diaz-Tocados, J.M.; Herencia, C.; Martinez-Moreno, J.M.; Montes de Oca, A.; Rodriguez-Ortiz, M.E.; Vergara, N.; Blanco, A.; Steppan, S.; Almaden, Y.; Rodriguez, M.; et al. Magnesium Chloride promotes Osteogenesis through Notch signaling activation and expansion of Mesenchymal Stem Cells. Sci. Rep. 2017, 7, 7839. [CrossRef] [PubMed]

158. Yee, N.S. Role of TRPM7 in Cancer: Potential as Molecular Biomarker and Therapeutic Target. Pharmaceuticals (Basel) 2017, 10, 39. [CrossRef]

159. Yang, H.; Kim, T.H.; Lee, G.S.; Hong, E.J.; Jeung, E.B. Comparing the expression patterns of placental magnesium/phosphorus-transporting channels between healthy and preeclamptic pregnancies. Mol. Reprod. Dev. 2014, 81, 851-860. [CrossRef]

160. Weintraub, A.Y.; Amash, A.; Eshkoli, T.; Piltcher Haber, E.; Bronfenmacher, B.; Sheiner, E.; Holcberg, G.; Huleihel, M. The effects of magnesium sulfate on placental vascular endothelial growth factor expression in preeclampsia. Hypertens. Pregnancy 2013, 32, 178-188. [CrossRef]

161. Costa, A.; Tejpar, S.; Prenen, H.; Van Cutsem, E. Hypomagnesaemia and targeted anti-epidermal growth factor receptor (EGFR) agents. Target. Oncol. 2011, 6, 227-233. [CrossRef] 